\title{
Targeted proteomic approach in prostatic tissue: a panel of potential biomarkers for cancer detection
}

\author{
Donatella Aiello ${ }^{1, *}$, Francesca Casadonte ${ }^{2, *}$, Rosa Terracciano ${ }^{2}$, Rocco Damiano ${ }^{2}$, \\ Rocco Savino ${ }^{2}$, Giovanni Sindona ${ }^{1}$, Anna Napoli ${ }^{1}$ \\ ${ }^{1}$ Department of Chemistry and Chemical Technologies, University of Calabria, Italy \\ ${ }^{2}$ Department of Health Sciences, Magna Græcia University of Catanzaro, Catanzaro, Italy \\ *These authors have contributed equally to this work
}

Correspondence to: Anna Napoli, email: amc.napoli@unical.it

Keywords: PCa tissue, biomarker, metabolic pathway, bodily fluids, proteome

Received: May 29, $2016 \quad$ Accepted: June 03, $2016 \quad$ Published: July 08, 2016

This is an open-access article distributed under the terms of the Creative Commons Attribution License, which permits unrestricted use, distribution, and reproduction in any medium, provided the original author and source are credited.

\section{ABSTRACT}

\begin{abstract}
Prostate cancer (PCa) is the sixth highest causes of cancer-related deaths in men. The molecular events underlying its behavior and evolution are not completely understood. Prostate-specific antigen (PSA) is the only approved Food and Drug Administration biomarker. A panel of ten stage-specific tumoral and adjacent non tumoral tissues from patients affected by PCa (Gleason score 6, 3+3; PSA $10 \div 19 \mathrm{ng} / \mathrm{ml}$ ) was investigated by MS-based proteomics approach. The proposed method was based on identifying the base-soluble proteins from tissue, established an efficient study, which lead to a deeper molecular perspective understanding of the PCa. A total of 164 proteins were found and $\mathbf{1 3 2}$ of these were evaluated differentially expressed in tumoral tissues. The Ingenuity Pathway Analysis (IPA) showed that among all dataset obtained, 105 molecules were involved in epithelial neoplasia with a p-value of 3.62E-05, whereas, only 11 molecules detected were ascribed to sentinel tissue and bodily fluids.
\end{abstract}

\section{INTRODUCTION}

Prostate cancer $(\mathrm{PCa})$ is the second most common cancer diagnosis worldwide and the sixth highest causes of cancer-related deaths in men [1]. Genetic, environmental factor, age, hormonal imbalance and diet denote the risk factor for PCa development. The detection and diagnosis of $\mathrm{PCa}$ are carried out by the measurement of serum prostate-specific antigen (PSA) level, digital rectal exam and histological inspection of prostate tissue biopsy [2]. PSA is the only biomarker approved by Food and Drug Administration (FDA). This test is useful for early diagnosis reducing the mortality, whereas the low sensitivity and specificity lead to overdiagnosis and overtreatment [3]. The misdiagnosis of $\mathrm{PCa}$ results in an non-predicable and aggressive treatment which may initiate a series of molecular events, which are not well understood. Therefore, to improve the diagnosis specificity and the clinical management the identification of additional biomarkers is desirable. DNA microarrays [4] can be used to measure $\mathrm{PCa}$ by providing the ability to compare changes in gene expression in the developing of PCa; however, they do not allow measurements of the protein levels. Proteomics represent a promising approach for the discovery and identification of specific molecules or set of proteins that are characteristics of a pathologic state [5]. Proteomics analysis of specific tissue can elucidate the mechanism of cells transformation from normal to cancerous status and provide a specific set of proteins to differentiate aggressive or indolent cancer forms. To date, analyses of protein levels in cancer have been performed by either using two-dimensional (2D) PAGE and/or surface enhanced laser desorption/ionization (SELDI) mass spectrometry [6]. Several studies describe the use of isobaric-tags for relative and absolute quantitation (iTRAQ) for the investigation of prostate tissue in order to identify potential markers for cancer diagnosis, prognosis or treatment. [7] Garbis et al. [8] analyzed prostate tissue from patients with benign prostatic hyperplasia (BPH) and with prostate cancer thought iTRAQ labelling. Sixty five differentially expressed proteins have been previously described as specific marker for prostate cancer cells. These were identified as: prostaglandin E synthase resulting from 
significant upregulation of proteins, alpha-1-antitrypsin, which is a well-known as biomarker for inflammation and $\alpha$-methylacyl CoA racemase. Sun et al. [9] analysed prostate tissue from $\mathrm{BPH}, \mathrm{PCa}$ and $\mathrm{BPH}$ with local prostatic intraepithelial neoplasm and identified periostin as a potential biomarker for prostate cancer. It is well known that carcinogenesis produces in biological fluids cancer molecular specific biomarkers. These biomarkers result from complex biological phenomena which are supported by a rich network of different cells such as fibroblasts, endothelial cells, immune and inflammatory cells, extra-cellular matrix and proteins produced by the malignant microenvironment [10]. In an effort to identify a set of specific molecules which are associated with cancer development, in prostate tissues and biological fluids, we have developed an alternative method based on the extraction of hydro-soluble tissue proteins followed by protein fractionation compatible with mass-spectrometry analysis. In addition, tumoral and histological adjacent benign tissues of prostate from patients with elevated PSA value and Gleason Grade were selected as case studies to identify and quantify potential prostate tumor markers [11, 12]. A selective solubilization procedure was adopted to extract hydrosoluble basic proteins from prostate tissue. Then, protein depletion was performed to remove interfering highly abundant proteins; this removal unmasks low abundance proteins of interest for further investigation. The proteins were then subjected to solution phase trypsin proteolysis followed by iTRAQ-labelling and finally analysed by LC-MALDI MS/MS. Using this approach we found 164 proteins. 132 proteins were differentially expressed, 11 proteins were expressed in bodily fluids and these can be used as potential cancer biomarkers for $\mathrm{PCa}$ diagnosis.

\section{RESULTS}

An alternative and rapid protocol has been developed for selective protein solubilization [13-15] from prostate tissue, followed by iTRAQ labelling, HPLC fractionation and MALDI MS/MS analysis to identify a set of specific markers for PCa diagnosis. The procedure was optimized on the swine prostate tissue which is considered the best classic biomedical model for human disease [16]. High abundant proteins were depleted by two different commercial columns using alternative MS-compatible buffers and the resulting fractions were visualized by SDS-PAGE in order to check the efficiency of the planned procedure (Figure S1). Multiple Affinity removal spin cartridge was chosen as the optimal depletion device because it is able to carry out several runs with no memory effect.

The optimized sample preparation procedure was used for human prostate tissue. SDS-PAGE and MALDITOF MS profiles of the resulting fractions are reported in Figure 1 and Figure SI2, respectively. The major proteins

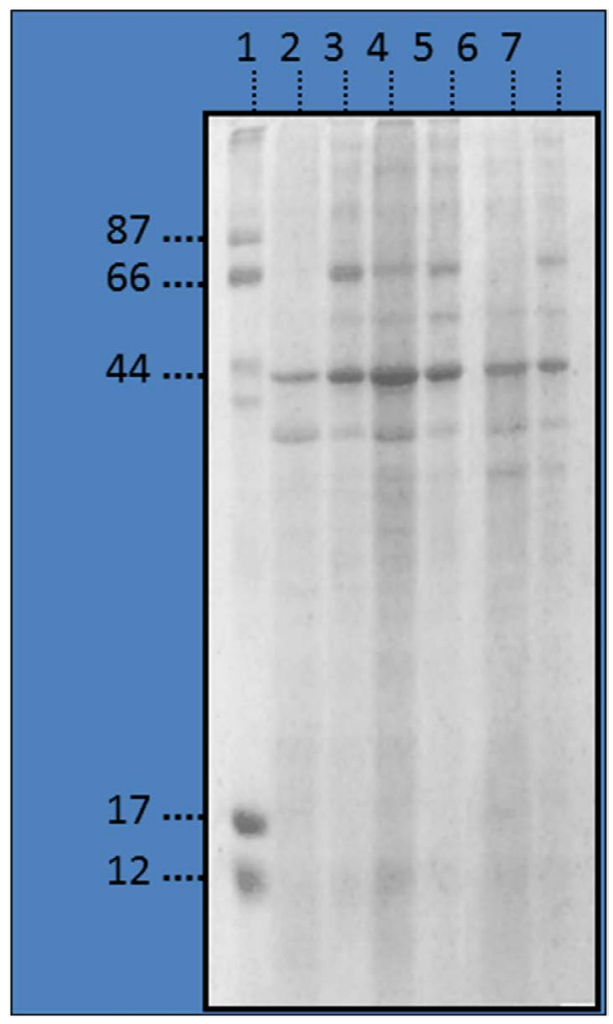

Figure 1: Electrophoresis profile of prostate human tissue. Lanes: 1. Marker. 2-3: Depleted and whole fractions from human tumoral (T) prostate tissue from patient A. 4-5: Depleted and whole fractions from human tumoral (T) prostate tissue from patient B. 6-7: Depleted and whole fractions from human non tumoral (NT) prostate tissue from patient B. 
are removed providing access to the next level of protein (hLA) as shown in Figure 1. SDS-PAGE shows different protein profiling of whole protein extracts (Figure 1, lines 3, 5 and 7) and hLA fractions (Figure 1, lines 3, 4 and 6). The experimental conditions for i-TRAQ quantitative analysis were modified (see experimental section). A total of 164 proteins were identified and 132 were considered differentially expressed between T and NT prostate tissue, with ion ratio of either $\geq 2$ or $\leq 0.5$ at $p$-value less than 0.05 for statistical significance (Table 1). Proteins were identified and quantified with no minus of three labelled peptides. The experiments were performed in triplicate and all peptide sequences are reported in Table SI2 and SI3 (Supporting Information).

The input data set containing all identified proteins from the iTRAQ LC-MS/MS analysis was uploaded into IPA [19]. The founded top five significant Molecular and Cellular Function associations with proteins are involved in Cellular Movement, Cellular Assembly - Organization, Cellular Development, Cellular Growth - Proliferation, and Gene Expression. Otherwise the top five obtained networks are all related to cellular proliferation, cellular death/survival and cancer (Supporting Information, Table SI3 A-F). IPA analysis evidenced that among all dataset, 105 molecules are involved in epithelial neoplasia with a p-value of 3.62E-05 (Table 1).

\section{DISCUSSION}

A crucial step in cancer control and prevention is the detection of disease as early as possible in order to allow effective interventions and therapies. Biomarkers are important as molecular signposts of the physiological state in specific cell at a definite time. In an effort to develop a comprehensive approach for biomarker-based prevention research it became primordial to draft a modern proteomic platform technology for biomarkers discovery and validation. Several studies have been focused on prostate cancer research through MS-based proteomic approaches [8] but biomarkers discovery remains a difficult task related to the complexity of the samples and the dynamic concentration of proteins. The mass spectrometry based proteomic approach described in this work is focused on the extraction, identification and quantitation of a base-soluble proteins subset from prostate tissue useful for diagnosis of human PCa. The choice for the analysis of stage-specific tumours (T) and healthy tissues adjacent to the tumour (NT) area could help in the elucidation of the molecular networks and mechanisms involved in pathogenesis. T and NT prostate tissue from the same individual were analysed since tissue samples show a wide biological variability particularly when they derive from different patients. The identification of basesoluble proteins could have the main advantage to be directly correlated to body fluids such as urine, which is enriched with proteins from PCa cells, hence giving the option to develop an alternative non-invasive biomarkers discovering method. The experimental design was planned to generate a consistent data set and to reduce the number of analytes handling, minimizing the result variability. The introduction of a pre-fractionation step prior to proteomic analysis reduce the sample complexity and improve the detection sensitivity of low-abundant proteins [20]. The buffers supplied by manufacture contain surfactants and salts that interfere with MALDI-TOF MS analysis, therefore we have developed a novel depletion protocol adopting saline solutions MS-compatible.

\section{Differentially expressed proteins}

Table 1 lists 164 proteins that were identified and quantified by Protein Pilot Paragon methods. The identified proteins were grouped in different classes which were based on their cellular location (Figure 2). The major parts of the proteins originated from the cytoplasm $(38,5 \%)$ and nucleus $(31,7 \%)$. The presence of membrane related proteins $(20,0 \%)$ confirms the high-throughput performance of the extraction step. The origins of the remaining proteins were as follows: secreted $(4,4 \%)$, ubiquitous (1\%) and -from extracellular space $(2,9 \%)$, while only a small part $(1,5 \%)$ was unspecified.

Table 1 list several proteins involved in transcriptional regulation. The transcription factors participate in the gene expression at the ends of all 19 of the know signal transduction and stress pathways. [21] An increase in the activity of the transcription factors is correlated with the various changes in the protein expression, protein stability, protein-protein interaction and post-translation modification [21]. The increase of many of these activities can affect the cancerous transformation by modifying the typical function of transcriptional co-activator or co-repressors. Among the family of the transcription receptor factor, the nuclear receptor coactivator 1 protein (NCOA1, Table 1 - row 91), also called SRC-1, identified as up-regulated,. SRC-1 is a co-activator of the androgen receptor (AR) mediated signalling pathway. The involvement of the NCOA1 in prostate cancer progression was supported by the recent study of Agoulnik et al. [22]. NCOA1 over expression in the metastatic prostate cancer occurs in primary tumors rather than the normal prostate. Agoulnik et al demonstrated that the ablation of NCOA1 in the androgendependent LNCaP prostate cancer cells, represses the activation of the AR target genes and it reduces the ARdependent cellular proliferation. Prohibitin (PHB, Table 1 - row 108) is an evolutionary conserved multifunctional protein that is upregulated in PCa samples and is also implicated in many cellular process [23, 24, 25]. Several studies have shown that the essential function of PHB is for cell proliferation and it as a crucial protein used for cancer cell growth and survival [26]. In accordance with our result, Umanni et al. [27]. examined biopsy 
Table 1: Identified proteins from tumoral and non tumoral prostate tissue by MS/MS data processing ${ }^{\mathrm{a}}$

\begin{tabular}{|c|c|c|c|c|c|c|c|c|}
\hline & $\begin{array}{l}\text { Accession } \\
\text { Number }\end{array}$ & Gene Name ${ }^{b}$ & Protein Name ${ }^{b}$ & $\mathbf{I P}^{\mathrm{c}}$ & MW(Da) ${ }^{\mathrm{c}}$ & Location $^{b}$ & $\begin{array}{l}\text { Biological Processes } \\
\text { and Molecular } \\
\text { Function }^{\text {b }}\end{array}$ & $\begin{array}{c}\text { Quantification } \\
117: 115^{\mathrm{a}}\end{array}$ \\
\hline 1. & P63104 & YWHAZ & $\begin{array}{l}\text { 14-3-3 protein zeta/ } \\
\text { delta* }^{*}\end{array}$ & 473 & 27745 & cytoplasm & $\begin{array}{l}\text { adapter protein } \\
\text { implicated in the } \\
\text { regulation of signaling } \\
\text { pathways negative } \\
\text { regulation of apoptotic } \\
\text { process }\end{array}$ & 380 \\
\hline 2. & Q9P2A4 & ABI3 & $\begin{array}{l}\text { ABI gene family } \\
\text { member } 3\end{array}$ & 499 & 39035 & cytoplasm & $\begin{array}{l}\text { regulation of cell } \\
\text { migration }\end{array}$ & 180 \\
\hline 3. & P68032 & ACTC1 & $\begin{array}{c}\text { Actin alpha cardiac } \\
\text { muscle } 1 *\end{array}$ & 523 & 42019 & cytoskeleton & $\begin{array}{l}\text { cell structure and } \\
\text { motility }\end{array}$ & 227 \\
\hline 4. & P25054 & $\mathbf{A P C}$ & $\begin{array}{c}\text { Adenomatous } \\
\text { polyposis coli protein* }\end{array}$ & 793 & 311646 & cytoplasm & $\begin{array}{l}\text { signal transduction } \\
\text { oncogenesis beta- } \\
\text { catenin binding, } \\
\text { protein kinase } \\
\text { regulator activity }\end{array}$ & 292 \\
\hline 5. & O95996 & APC2 & $\begin{array}{c}\text { Adenomatous } \\
\text { polyposis coli protein } 2\end{array}$ & 908 & 243949 & $\begin{array}{l}\text { cytoplasm and } \\
\text { cell membrane }\end{array}$ & $\begin{array}{l}\text { promotes rapid } \\
\text { degradation of } \\
\text { CTNNB1 and may } \\
\text { function as a tumor } \\
\text { suppressor May } \\
\text { function in Wnt } \\
\text { signaling }\end{array}$ & 358 \\
\hline 6. & Q08462 & ADCY2 & Adenylate cyclase* & 840 & 123603 & $\begin{array}{l}\text { Citoplasm/ } \\
\text { membrane }\end{array}$ & $\begin{array}{l}\text { membrane-bound and } \\
\text { Adenylate cyclase } \\
\text { activity }\end{array}$ & 320 \\
\hline 7. & P51825 & AFF1 & $\begin{array}{l}\text { AF4/FMR2 family } \\
\text { member } 1^{*}\end{array}$ & 926 & 131422 & nucleus & $\begin{array}{l}\text { oncogene transcription } \\
\text { factor- }\end{array}$ & 237 \\
\hline 8. & P10696 & ALPPL2 & $\begin{array}{l}\text { Alkaline phosphatase } \\
\text { placental-like }\end{array}$ & 590 & 57377 & membrane & $\begin{array}{l}\text { hydrolase with } \\
\text { biological process } \\
\text { unclassified }\end{array}$ & 145 \\
\hline 9. & Q99490 & AGAP2 & $\begin{array}{c}\text { Arf-GAP with GTPase } \\
\text { ANK repeat and PH } \\
\text { domain-containing } \\
\text { protein } 2^{*}\end{array}$ & 991 & 124674 & $\begin{array}{l}\text { cytoplasm and } \\
\text { nucleus }\end{array}$ & $\begin{array}{l}\text { protein transport } \\
\text { oncogenic } \\
\text { overexpressed in } \\
\text { cancer cells prevents } \\
\text { apoptosis and } \\
\text { promotes cancer cell } \\
\text { invasion }\end{array}$ & 302 \\
\hline 10. & Q8TF01 & PNSIR & $\begin{array}{l}\text { Arginine/serine-rich } \\
\text { protein PNISR* }\end{array}$ & 1002 & 92577 & $\begin{array}{l}\text { Nucleus } \\
\text { cytoplasm }\end{array}$ & transcription system & 159 \\
\hline 11. & 014525 & ASTN1 & $\begin{array}{l}\text { Astrotactin } 1 \\
\text { (Fragment) } *\end{array}$ & 509 & 144913 & membrane & cell adhesion & 255 \\
\hline 12. & Q4LE39 & ARID4B & $\begin{array}{c}\text { AT-rich interactive } \\
\text { domain-containing } \\
\text { protein } 4 \mathrm{~B}^{*}\end{array}$ & 504 & 147809 & $\begin{array}{l}\text { Nucleus and } \\
\text { cytoplasm }\end{array}$ & $\begin{array}{l}\text { transcriptional } \\
\text { repressor }\end{array}$ & 217 \\
\hline 13. & 075815 & BCAR3 & $\begin{array}{l}\text { Breast cancer anti- } \\
\text { estrogen resistance } \\
\text { protein } 3\end{array}$ & 819 & 92566 & intracellular & $\begin{array}{l}\text { guanine nucleotide } \\
\text { responsive factor } \\
\text { signal trasduction }\end{array}$ & 721 \\
\hline 14. & Q9UIF8 & BAZ2B & $\begin{array}{c}\text { Bromodomain adjacent } \\
\text { to zinc finger domain } \\
\text { protein } 2 \mathrm{~B}^{*}\end{array}$ & 613 & 240459 & nucleus & $\begin{array}{l}\text { transcriptional } \\
\text { regulation }\end{array}$ & 164 \\
\hline
\end{tabular}




\begin{tabular}{|c|c|c|c|c|c|c|c|c|}
\hline & $\begin{array}{l}\text { Accession } \\
\text { Number }\end{array}$ & Gene Name ${ }^{b}$ & Protein Name ${ }^{b}$ & $\mathbf{I P}^{\mathbf{c}}$ & $\operatorname{MW}(\mathbf{D a})^{\mathrm{c}}$ & Location $^{b}$ & $\begin{array}{c}\text { Biological Processes } \\
\text { and Molecular } \\
\text { Function }^{\mathrm{b}}\end{array}$ & $\begin{array}{c}\text { Quantification } \\
117: 115^{\mathrm{a}}\end{array}$ \\
\hline 15. & Q9NYQ7 & CELSR3 & $\begin{array}{c}\text { Cadherin EGF LAG } \\
\text { seven-pass G-type } \\
\text { receptor } 3\end{array}$ & 623 & 358185 & cell membrane & cell signaling receptor & 295 \\
\hline 16. & 015484 & CAPN5 & Calpain-5* & 757 & 73169 & cell surface & $\begin{array}{l}\text { hydrolase involved in } \\
\text { protein metabolism } \\
\text { and modification }\end{array}$ & 116 \\
\hline 17. & Q66K79 & CPZ & $\begin{array}{c}\text { Carboxypeptidase } \mathbf{Z} \\
\text { precursor } *\end{array}$ & 822 & 73655 & $\begin{array}{c}\text { secreted }> \\
\text { extracellular } \\
\text { space }\end{array}$ & $\begin{array}{l}\text { metalloprotease } \\
\text { biological process } \\
\text { unclassified }\end{array}$ & 389 \\
\hline 18. & P35222 & CTNNB1 & Catenin beta-1* & 553 & 85497 & $\begin{array}{l}\text { cytoplasm } \\
\text { nucleus cell } \\
\text { membrane }\end{array}$ & $\begin{array}{l}\text { cell adhesion } \\
\text { transcription } \\
\text { regulation and } \\
\text { oncogenesis }\end{array}$ & 210 \\
\hline 19. & Q96P48 & ARAP1 & Centaurin-delta-2 & 586 & 162192 & $\begin{array}{c}\text { Golgi } \\
\text { apparatus } \\
\text { membrane } \\
\text { cytoplasm }\end{array}$ & GTPase activation & 578 \\
\hline 20. & Q9HC77 & CENPJ & Centromere protein $\mathbf{J}^{*}$ & 623 & 153000 & $\begin{array}{l}\text { Cytoplasm } \\
\text { cytoskeleton }\end{array}$ & $\begin{array}{l}\text { plays an important role } \\
\text { in cell division and } \\
\text { centrosome function }\end{array}$ & 159 \\
\hline 21. & 014647 & CHD2 & $\begin{array}{c}\text { Chromodomain- } \\
\text { helicase-DNA-binding } \\
\text { protein } 2 \text { (CHD-2) * }\end{array}$ & 822 & 211344 & nucleus & $\begin{array}{l}\text { transcription } \\
\text { regulation DNA- } \\
\text { binding helicase }\end{array}$ & 149 \\
\hline 22. & Q8TD26 & CDH6 & $\begin{array}{c}\text { Chromodomain- } \\
\text { helicase-DNA-binding } \\
\text { protein } 6^{*}\end{array}$ & 590 & 305412 & nucleus & transcription regulator & 353 \\
\hline 23. & Q02388 & COL7A1 & Collagen alpha 1 (VII) * & 595 & 295220 & $\begin{array}{c}\text { secreted } \\
\text { extracellular } \\
\text { space }\end{array}$ & $\begin{array}{l}\text { extracellular matrix } \\
\text { structural constituent }\end{array}$ & 207 \\
\hline 24. & P08123 & COL1A2 & $\begin{array}{c}\text { Collagen alpha 2(I) } \\
\text { chain* }\end{array}$ & 908 & 129314 & $\begin{array}{c}\text { secreted } \\
\text { extracellular } \\
\text { space }\end{array}$ & $\begin{array}{l}\text { extracellular matrix } \\
\text { structural constituent }\end{array}$ & 319 \\
\hline 25. & P08572 & COL4A2 & $\begin{array}{c}\text { Collagen alpha } 2(I V) \\
\text { chain* }\end{array}$ & 885 & 167553 & $\begin{array}{c}\text { secreted } \\
\text { extracellular } \\
\text { space }\end{array}$ & $\begin{array}{l}\text { extracellular matrix } \\
\text { structural constituent }\end{array}$ & 312 \\
\hline 26. & P12277 & CKB & $\begin{array}{c}\text { Creatine kinase } \\
\text { B-type* }\end{array}$ & 535 & 42644 & cytoplasm & $\begin{array}{l}\text { central role in energy } \\
\text { transduction in tissues }\end{array}$ & 449 \\
\hline 27. & Q9P0U4 & CXXC1 & $\begin{array}{c}\text { CXXC-type zinc finger } \\
\text { protein } 1\end{array}$ & 861 & 75712 & nucleus & $\begin{array}{l}\text { transcription } \\
\text { regulation }\end{array}$ & 110 \\
\hline 28. & Q9NZJ0 & DTL & $\begin{array}{l}\text { Denticleless protein } \\
\text { homolog }\end{array}$ & 911 & 79468 & $\begin{array}{l}\text { Nucleus and } \\
\text { cytoplasm }\end{array}$ & $\begin{array}{c}\text { cell cycle control } \\
\text { DNA damage response } \\
\text { and translation DNA } \\
\text { synthesis }\end{array}$ & 314 \\
\hline 29. & P17661 & DES & Desmin * & 521 & 53536 & cytoplasm & $\begin{array}{l}\text { cytoskeletal protein } \\
\text { binding muscle protein }\end{array}$ & 378 \\
\hline 30. & Q08554 & DSC1 & $\begin{array}{l}\text { Desmocollin 1A/1B } \\
\text { precursor }\end{array}$ & 525 & 99987 & cell membrane & $\begin{array}{l}\text { cell adhesion-mediated } \\
\text { signaling }\end{array}$ & 255 \\
\hline 31. & Q14117 & DPYS & Dihydropyrimidinase * & 681 & 56630 & cytoplasm & $\begin{array}{l}\text { nucleoside nucleotide } \\
\text { and nucleic acid } \\
\text { metabolism }\end{array}$ & 630 \\
\hline & & & & & & & & (Continued) \\
\hline
\end{tabular}




\begin{tabular}{|c|c|c|c|c|c|c|c|c|}
\hline & $\begin{array}{l}\text { Accession } \\
\text { Number }^{b}\end{array}$ & Gene Name ${ }^{b}$ & Protein Name $^{b}$ & $\mathbf{I P}^{\mathbf{c}}$ & MW(Da) ${ }^{\mathrm{c}}$ & Location $^{\text {b }}$ & $\begin{array}{c}\text { Biological Processes } \\
\text { and Molecular } \\
\text { Function }^{\mathbf{b}}\end{array}$ & $\begin{array}{c}\text { Quantification } \\
117: 115^{\mathrm{a}}\end{array}$ \\
\hline 32. & Q9Y485 & DMXL1 & DmX-like 1 protein * & 591 & 337839 & $\begin{array}{l}\text { extracellular } \\
\text { space }\end{array}$ & unknown & 614 \\
\hline 33. & Q9NPF5 & DMAP1 & $\begin{array}{l}\text { DNA methyltransferase } \\
\text { 1-associated protein } 1\end{array}$ & 951 & 52993 & $\begin{array}{l}\text { Cytoplasm } \\
\text { and nucleus }\end{array}$ & $\begin{array}{l}\text { transcription } \\
\text { repression and } \\
\text { activation }\end{array}$ & 227 \\
\hline 34. & Q92878 & RAD50 & $\begin{array}{l}\text { DNA repair protein } \\
\text { RAD50* }\end{array}$ & 647 & 153892 & nucleus & hydrolase & 401 \\
\hline 35. & 060870 & KIN & $\begin{array}{l}\text { DNA/RNA-binding } \\
\text { protein KIN17 }\end{array}$ & 907 & 45374 & $\begin{array}{c}\text { nucleus and } \\
\text { cytoplasm }\end{array}$ & $\begin{array}{l}\text { involved in DNA } \\
\text { replication and the } \\
\text { cellular response to } \\
\text { DNA damage }\end{array}$ & 050 \\
\hline 36. & Q8TD84 & DSCAML1 & $\begin{array}{c}\text { Down syndrome cell } \\
\text { adhesion molecule-like } \\
\text { protein } 1^{*}\end{array}$ & 843 & 224463 & cell membrane & $\begin{array}{l}\text { cell adhesion and } \\
\text { neurogenesis }\end{array}$ & 380 \\
\hline 37. & Q96DT5 & DNAH11 & $\begin{array}{c}\text { Dynein heavy chain } 11 \\
\text { axonemal* }\end{array}$ & 603 & 521043 & cytoplasm & $\begin{array}{l}\text { force generating } \\
\text { protein of respiratory } \\
\text { cilia produces force } \\
\text { towards the minus } \\
\text { ends of microtubules } \\
\text { and has ATPase } \\
\text { activity }\end{array}$ & 492 \\
\hline 38. & Q8WXX0 & DNAH7 & $\begin{array}{c}\text { Dynein heavy chain } 7 \\
\text { axonemal * }\end{array}$ & 570 & 461159 & $\begin{array}{l}\text { cytoplasm } \\
\text { cytoskeleton } \\
\text { microtubule }\end{array}$ & $\begin{array}{l}\text { force generating } \\
\text { protein of respiratory } \\
\text { cilia produces force } \\
\text { towards the minus } \\
\text { ends of microtubules } \\
\text { and has ATPase } \\
\text { activity }\end{array}$ & 443 \\
\hline 39. & Q03001 & DST & Dystonin* & 514 & 860662 & $\begin{array}{l}\text { cytoplasm and } \\
\text { cytoskeleton }\end{array}$ & $\begin{array}{l}\text { integrator of } \\
\text { intermediate filaments } \\
\text { involved in actin } \\
\text { and microtubule } \\
\text { cytoskeleton networks }\end{array}$ & 428 \\
\hline 40. & P14625 & HSP90B1 & Endoplasmin* & 476 & 92469 & $\begin{array}{l}\text { endoplasmic } \\
\text { reticulum }\end{array}$ & molecular chaperone & 391 \\
\hline 41. & Q96J88 & EPSTI1 & $\begin{array}{c}\text { epithelial stromal } \\
\text { interaction protein } 1\end{array}$ & 990 & 36793 & unspecified & unknown & 265 \\
\hline 42. & Q8TAM0 & GPR62 & $\begin{array}{l}\text { G protein-coupled } \\
\text { receptor } 62^{*}\end{array}$ & 1099 & 37619 & $\begin{array}{l}\text { Cell } \\
\text { membrane }\end{array}$ & $\begin{array}{l}\text { G-protein coupled } \\
\text { receptor }\end{array}$ & 301 \\
\hline 43. & O94808 & GFPT2 & $\begin{array}{l}\text { Glucosamine- } \\
\text { fructose-6-phosphate } \\
\text { aminotransferase } \\
\text { [isomerizing] } 2\end{array}$ & 703 & 76931 & cytosol & aminotransferase & 224 \\
\hline 44. & Q6PCE3 & PGM2L1 & $\begin{array}{c}\text { Glucose 16-bisphoshate } \\
\text { syntase }\end{array}$ & 681 & 70442 & cytosol & $\begin{array}{l}\text { glucose metabolism } \\
\text { isomerase and } \\
\text { transferase }\end{array}$ & 303 \\
\hline 45. & P30711 & GSTT1 & $\begin{array}{c}\text { Glutathione } \\
\text { S-transferase theta } 1 *\end{array}$ & 701 & 27335 & cytoplasm & $\begin{array}{c}\text { glutathione transferase } \\
\text { activity }\end{array}$ & 173 \\
\hline 46. & Q9NU53 & GINM1 & $\begin{array}{l}\text { Glycoprotein integral } \\
\text { membrane protein } 1\end{array}$ & 481 & 36840 & membrane & unspecified & 127 \\
\hline
\end{tabular}




\begin{tabular}{|c|c|c|c|c|c|c|c|c|}
\hline & $\begin{array}{l}\text { Accession } \\
\text { Number }^{b}\end{array}$ & Gene Name ${ }^{b}$ & Protein Name ${ }^{b}$ & $\mathbf{I P}^{\mathbf{c}}$ & MW(Da) ${ }^{\mathrm{c}}$ & Location $^{\text {b }}$ & $\begin{array}{c}\text { Biological Processes } \\
\text { and Molecular } \\
\text { Function }^{b}\end{array}$ & $\begin{array}{c}\text { Quantification } \\
117: 115^{\mathrm{a}}\end{array}$ \\
\hline 47. & Q14789 & GOLGB1 & $\begin{array}{c}\text { Golgin subfamily B } \\
\text { member } 1^{*}\end{array}$ & 496 & 376019 & $\begin{array}{c}\text { Golgi } \\
\text { apparatus and } \\
\text { membrane }\end{array}$ & unknown & 050 \\
\hline 48. & Q99062 & CSF3R & $\begin{array}{c}\text { Granulocyte colony } \\
\text { stimulating factor } \\
\text { receptor* }\end{array}$ & 576 & 92156 & cell membrane & receptor & 354 \\
\hline 49. & Q03113 & GNA12 & $\begin{array}{l}\text { Guanine nucleotide- } \\
\text { binding protein } \\
\text { subunit alpha-12* }\end{array}$ & 984 & 44279 & membrane & $\begin{array}{c}\text { modulators or } \\
\text { transducers in various } \\
\text { trans-membrane } \\
\text { signaling systems } \\
\text { controller of cell } \\
\text { migration through the } \\
\text { TOR signaling cascade }\end{array}$ & 379 \\
\hline 50. & Q96LI6 & HSFY1 & $\begin{array}{c}\text { Heat shock } \\
\text { transcription factor } \\
\text { Y-linked }\end{array}$ & 668 & 45107 & $\begin{array}{l}\text { nucleus } \\
\text { cytoplasm }\end{array}$ & $\begin{array}{l}\text { transcription } \\
\text { regulation }\end{array}$ & 110 \\
\hline 51. & P69905 & HBA1 & $\begin{array}{c}\text { Hemoglobin subunit } \\
\text { alpha }\end{array}$ & 872 & 15258 & cytosol & oxygen transporter & 497 \\
\hline 52. & P68871 & HBB & $\begin{array}{c}\text { Hemoglobin subunit } \\
\text { Beta }\end{array}$ & 674 & 15998 & cytosol & oxygen transporter & 271 \\
\hline 53. & P09105 & HBQ1 & $\begin{array}{c}\text { Hemoglobin subunit } \\
\text { theta-1 }\end{array}$ & 709 & 15508 & cytosol & oxygen transporter & 288 \\
\hline 54. & Q8TEK3 & DOT1L & $\begin{array}{c}\text { Histone-lysine } \\
\text { N-methyltransferase } \\
\text { H3 lysine-79 specific * }\end{array}$ & 939 & 184853 & nucleus & chromatin regulator & 304 \\
\hline 55. & P17482 & HOXB9 & $\begin{array}{l}\text { Homeobox protein } \\
\text { Hox-B9* }\end{array}$ & 901 & 28059 & nucleus & $\begin{array}{l}\text { sequence-specific } \\
\text { transcription factor }\end{array}$ & 249 \\
\hline 56. & Q9HAS2 & HIPK3 & $\begin{array}{l}\text { Homeodomain- } \\
\text { interacting protein } \\
\text { kinase } 3^{*}\end{array}$ & 716 & 133743 & $\begin{array}{l}\text { cytoplasm and } \\
\text { nucleus }\end{array}$ & $\begin{array}{l}\text { serine/threonine- } \\
\text { protein kinase } \\
\text { involved in } \\
\text { transcription } \\
\text { regulation apoptosis } \\
\text { and steroidogenic }\end{array}$ & 907 \\
\hline 57. & P42858 & HTT & Huntingtin & 581 & 347603 & $\begin{array}{l}\text { cytoplasm and } \\
\text { nucleus }\end{array}$ & $\begin{array}{l}\text { may play a role in } \\
\text { microtubule-mediated } \\
\text { transport or vesicle } \\
\text { function Protein } \\
\text { binding }\end{array}$ & 388 \\
\hline 58. & Q9Y4L1 & HYOU1 & $\begin{array}{c}\text { Hypoxia up-regulated } \\
\text { protein } 1^{*}\end{array}$ & 516 & 111335 & nucleus & $\begin{array}{l}\text { protein metabolism } \\
\text { and modification }\end{array}$ & 229 \\
\hline 59. & P23677 & ITPKA & $\begin{array}{c}\text { Inositol } \\
\text { 145-trisphosphate } \\
\text { 3-kinase A }\end{array}$ & 759 & 51009 & cytosol & kinase & 299 \\
\hline 60. & 015503 & INSIG1 & $\begin{array}{l}\text { Insulin-induced } \\
\text { protein } 1 *\end{array}$ & 908 & 29987 & $\begin{array}{l}\text { endoplasmic } \\
\text { reticulum } \\
\text { membrane }\end{array}$ & $\begin{array}{l}\text { protein binding may } \\
\text { play a role in growth } \\
\text { and differentiation of } \\
\text { tissues involved in } \\
\text { metabolic control and } \\
\text { has a regulatory role } \\
\text { during G0/G1 transition } \\
\text { of cell growth }\end{array}$ & 098 \\
\hline
\end{tabular}




\begin{tabular}{|c|c|c|c|c|c|c|c|c|}
\hline & $\begin{array}{l}\text { Accession } \\
\text { Number }^{b}\end{array}$ & Gene Name & Protein Name $^{b}$ & $\mathbf{I P}^{\mathbf{c}}$ & MW(Da) ${ }^{c}$ & Location $^{b}$ & $\begin{array}{c}\text { Biological Processes } \\
\text { and Molecular } \\
\text { Function }^{\mathbf{b}}\end{array}$ & $\begin{array}{c}\text { Quantification } \\
117: 115^{\mathrm{a}}\end{array}$ \\
\hline 61. & P24593 & IGFBP5 & $\begin{array}{l}\text { Insulin-like growth } \\
\text { factor binding protein } \\
5 \text { precursor* }\end{array}$ & 858 & 30570 & secreted & $\begin{array}{l}\text { signal transduction } \\
\text { and cellular protein } \\
\text { metabolic process }\end{array}$ & 306 \\
\hline 62. & Q9BR39 & JPH2 & Junctophilin 2 & 882 & 74222 & cell membrane & $\begin{array}{l}\text { contribute to the } \\
\text { formation of junctional } \\
\text { membrane complexes } \\
\text { and to the construction } \\
\text { of skeletal muscle } \\
\text { triad junctions }\end{array}$ & 477 \\
\hline 63. & Q01546 & KRT76 & $\begin{array}{l}\text { Keratin type II } \\
\text { cytoskeletal } 2 \text { oral }\end{array}$ & 838 & 65841 & cytoskeletal & $\begin{array}{l}\text { cell structure and } \\
\text { motility }\end{array}$ & 293 \\
\hline 64. & Q96L93 & KIF16B & $\begin{array}{c}\text { Kinesin-like protein } \\
\text { KIF-16B* }\end{array}$ & 586 & 152011 & cytoplasm & $\begin{array}{l}\text { motor protein involved } \\
\text { in endosome transport } \\
\text { and receptor recycling } \\
\text { and degradation }\end{array}$ & 456 \\
\hline 65. & Q8N4N8 & KIF2B & $\begin{array}{c}\text { Kinesin-like protein } \\
\text { KIF2B* }\end{array}$ & 889 & 76254 & cytoplasm & $\begin{array}{l}\text { motor protein required } \\
\text { for spindle assembly } \\
\text { and chromosome } \\
\text { movement }\end{array}$ & 470 \\
\hline 66. & Q32MZ4 & LRRFIP1 & $\begin{array}{c}\text { Leucine-rich repeat } \\
\text { flightless-interacting } \\
\text { protein } 1^{*}\end{array}$ & 459 & 89253 & $\begin{array}{l}\text { nucleus and } \\
\text { cytoplasm }\end{array}$ & $\begin{array}{l}\text { transcriptional } \\
\text { repressor }\end{array}$ & 381 \\
\hline 67. & Q9UNZ5 & C19orf53 & $\begin{array}{l}\text { Leydig cell tumor } 10 \\
\text { kDa protein homolog }\end{array}$ & 1155 & 10577 & nucleus & $\begin{array}{l}\text { potential role in } \\
\text { hyper-calcemia of } \\
\text { malignancy }\end{array}$ & 449 \\
\hline 68. & Q9H2C1 & LHX5 & $\begin{array}{c}\text { LIM/homeobox protein } \\
\text { Lhx5 }\end{array}$ & 787 & 44406 & nucleus & $\begin{array}{l}\text { transcription } \\
\text { regulation }\end{array}$ & 412 \\
\hline 69. & 075334 & PPFIA2 & Liprin-alpha2* & 580 & 143291 & $\begin{array}{l}\text { cytoplasm and } \\
\text { cell surface }\end{array}$ & protein binding & 261 \\
\hline 70. & Q9NZR2 & LRP1B & $\begin{array}{l}\text { Low-density } \\
\text { lipoprotein receptor- } \\
\text { related protein } 1 \mathrm{~B}^{*}\end{array}$ & 509 & 515498 & membrane & $\begin{array}{l}\text { cell surface } \\
\text { proteins involved in } \\
\text { endocytosis }\end{array}$ & 261 \\
\hline 71. & Q9H239 & MMP28 & $\begin{array}{c}\text { Matrix } \\
\text { metalloproteinase-28 }\end{array}$ & 970 & 58939 & $\begin{array}{l}\text { Secreted/ } \\
\text { extracellular } \\
\text { space }\end{array}$ & $\begin{array}{l}\text { could play a role in } \\
\text { tissues homeostasis } \\
\text { and repair }\end{array}$ & 282 \\
\hline 72. & Q9NR99 & MXRA5 & $\begin{array}{l}\text { Matrix-remodeling- } \\
\text { associated protein } 5^{*}\end{array}$ & 857 & 312150 & secreted & $\begin{array}{l}\text { unknown but it is } \\
\text { overexpressed in } \\
\text { centenarians }\end{array}$ & 332 \\
\hline 73. & Q96JG8 & MAGED4 & $\begin{array}{c}\text { Melanoma-associated } \\
\text { antigen D4 }\end{array}$ & 634 & 81378 & unspecified & tumor antigen & 214 \\
\hline 74. & Q8NFU7 & TET1 & $\begin{array}{c}\text { Methylcytosine } \\
\text { dioxygenase TET1* }\end{array}$ & 853 & 235309 & nucleus & $\begin{array}{l}\text { transcription } \\
\text { regulation activator } \\
\text { and regulator }\end{array}$ & 067 \\
\hline 75. & P11137 & MAP2 & $\begin{array}{c}\text { Microtubule-associated } \\
\text { protein } 2^{*}\end{array}$ & 482 & 199526 & cytoplasm & $\begin{array}{l}\text { may stabilize the } \\
\text { microtubules against } \\
\text { depolymerization }\end{array}$ & 272 \\
\hline 76. & Q9NU22 & MDN1 & Midasin* & 546 & 632820 & nucleus & $\begin{array}{l}\text { nuclear chaperone } \\
\text { required for } \\
\text { maturation and nuclear } \\
\text { export of pre- } 60 \mathrm{~S} \\
\text { ribosome subunits }\end{array}$ & 449 \\
\hline
\end{tabular}




\begin{tabular}{|c|c|c|c|c|c|c|c|c|}
\hline & $\begin{array}{l}\text { Accession } \\
\text { Number }^{b}\end{array}$ & Gene Name ${ }^{b}$ & Protein Name ${ }^{b}$ & $\mathbf{I P}^{\mathbf{c}}$ & MW(Da) ${ }^{\mathbf{c}}$ & Location $^{b}$ & $\begin{array}{l}\text { Biological Processes } \\
\text { and Molecular } \\
\text { Function }^{\mathrm{b}}\end{array}$ & $\begin{array}{c}\text { Quantification } \\
117: 115^{\mathrm{a}}\end{array}$ \\
\hline 77. & P08235 & NR3C2 & $\begin{array}{l}\text { Mineralocorticoid } \\
\text { receptor }(\mathrm{MR}) *\end{array}$ & 722 & 107067 & $\begin{array}{l}\text { cytoplasm } \\
\text { nucleus } \\
\text { endoplasmic } \\
\text { reticulum } \\
\text { membrane }\end{array}$ & $\begin{array}{l}\text { nuclear hormone } \\
\text { receptor and } \\
\text { transcription factor }\end{array}$ & 262 \\
\hline 78. & 060336 & MAPKBP1 & $\begin{array}{c}\text { Mitogen-activated } \\
\text { protein kinase-binding } \\
\text { protein } 1\end{array}$ & 631 & 163818 & unknown & $\begin{array}{l}\text { involved in JNK } \\
\text { signaling pathway }\end{array}$ & 500 \\
\hline 79. & Q8WV50 & BUB1B & $\begin{array}{c}\text { Mitotic checkpoint } \\
\text { serine/threonine- } \\
\text { protein kinase BUB1 } \\
\text { beta* }\end{array}$ & 520 & 119545 & $\begin{array}{l}\text { cytoplasm } \\
\text { nucleus } \\
\text { cytoskeleton }\end{array}$ & $\begin{array}{l}\text { essential component of } \\
\text { the mitotic checkpoint } \\
\text { with kinase activity }\end{array}$ & 237 \\
\hline 80. & P02686 & MBP & Myelin basic protein * & 979 & 33117 & $\begin{array}{l}\text { peripheral } \\
\text { membrane } \\
\text { protein }\end{array}$ & $\begin{array}{c}\text { formation and } \\
\text { stabilization of myelin } \\
\text { membrane }\end{array}$ & 262 \\
\hline 81. & P60660 & MYL6 & $\begin{array}{l}\text { Myosin light } \\
\text { polypeptide } 6\end{array}$ & 446 & 16961 & cytoskeleton & muscle protein & 213 \\
\hline 82. & P35749 & MYH11 & Myosin-11* & 542 & 227339 & $\begin{array}{l}\text { Cytoskeleton } \\
\text { and cytosol }\end{array}$ & muscle contraction & 227 \\
\hline 83. & Q9UKX3 & MYH13 & Myosin-13* & 553 & 223605 & cytoplasm & muscle contraction & 693 \\
\hline 84. & Q8WXH0 & SYNE2 & Nesprin-2* & 526 & 796442 & ubiquitous & $\begin{array}{l}\text { involved in the } \\
\text { maintenance of } \\
\text { nuclear organization } \\
\text { and structural integrity }\end{array}$ & 191 \\
\hline 85. & Q8NF91 & SYNE1 & Nesprin-1* & 537 & 1011086 & $\begin{array}{c}\text { Nuclear } \\
\text { cytoplasm } \\
\text { cytoskeleton } \\
\text { and membrane }\end{array}$ & $\begin{array}{l}\text { involved in the } \\
\text { maintenance of } \\
\text { nuclear organization } \\
\text { and structural integrity }\end{array}$ & 222 \\
\hline 86. & Q9ULB1 & NRXN1 & Neurexin-1* & 561 & 161883 & cell membrane & $\begin{array}{l}\text { cell surface protein } \\
\text { involved in cell-cell- } \\
\text { interactions exocytosis } \\
\text { of secretory granules } \\
\text { and regulation of } \\
\text { signal transmission }\end{array}$ & 416 \\
\hline 87. & Q8NFP9 & NBEA & Neurobeachin* & 578 & 327822 & $\begin{array}{c}\text { cytoplasm } \\
\text { and peripheral } \\
\text { membrane }\end{array}$ & $\begin{array}{c}\text { protein localization } \\
\text { anchoring/targeting } \\
\text { kinase A to the } \\
\text { membrane }\end{array}$ & 359 \\
\hline 88. & Q6KC79 & NIPBL & Nipped-B-like protein * & 809 & 316051 & nucleus & $\begin{array}{l}\text { involved in sister } \\
\text { chromatid cohesion }\end{array}$ & 236 \\
\hline 89. & P04198 & MYCN & $\begin{array}{l}\text { N-myc proto-oncogene } \\
\text { protein* }\end{array}$ & 545 & 49561 & nucleus & $\begin{array}{l}\text { transcription factor } \\
\text { proto-oncogene }\end{array}$ & 146 \\
\hline 90. & P23497 & SP100 & $\begin{array}{c}\text { Nuclear autoantigen } \\
\text { Sp-100 }\end{array}$ & 483 & 53768 & $\begin{array}{l}\text { nucleus and } \\
\text { cytoplasm }\end{array}$ & $\begin{array}{l}\text { transcription } \\
\text { regulation and tumor } \\
\text { suppressor }\end{array}$ & 168 \\
\hline
\end{tabular}

(Continued) 


\begin{tabular}{|c|c|c|c|c|c|c|c|c|}
\hline & $\begin{array}{l}\text { Accession } \\
\text { Number }^{\mathrm{b}}\end{array}$ & Gene Name ${ }^{\mathrm{b}}$ & Protein Name $^{\mathrm{b}}$ & $\mathbf{I P}^{\mathbf{c}}$ & MW(Da) ${ }^{\mathrm{c}}$ & Location $^{b}$ & $\begin{array}{c}\text { Biological Processes } \\
\text { and Molecular } \\
\text { Function }^{\mathrm{b}}\end{array}$ & $\begin{array}{c}\text { Quantification } \\
117: 115^{\mathrm{a}}\end{array}$ \\
\hline 91. & Q15788 & NCOA1 & $\begin{array}{l}\text { Nuclear receptor } \\
\text { coactivator } 1^{*}\end{array}$ & 583 & 156757 & nucleus & $\begin{array}{l}\text { binds nuclear receptors } \\
\text { and stimulates the } \\
\text { transcriptional } \\
\text { activities in a } \\
\text { hormone-dependent } \\
\text { fashion Involved } \\
\text { in the coactivation } \\
\text { of different nuclear } \\
\text { receptors and mediated } \\
\text { by STAT3 STAT5A } \\
\text { STAT5B and STAT6 } \\
\text { transcription factors }\end{array}$ & 292 \\
\hline 92. & 000482 & NR5A2 & $\begin{array}{c}\text { Nuclear receptor } \\
\text { subfamily } 5 \text { group A } \\
\text { member } 2^{*}\end{array}$ & 808 & 61331 & nucleus & $\begin{array}{l}\text { transcription } \\
\text { regulation }\end{array}$ & 237 \\
\hline 93. & Q5VST9 & OBSCN & Obscurin* & 569 & 868484 & cytoplasm & $\begin{array}{l}\text { involved in } \\
\text { miofibrillogenesis }\end{array}$ & 225 \\
\hline 94. & Q9C0B5 & ZDHHC5 & $\begin{array}{c}\text { Palmithoyltransferase } \\
\text { ZDHHC5 }\end{array}$ & 917 & 77545 & cell membrane & acyltrasferase & 202 \\
\hline 95. & P54317 & PNLIPRP2 & $\begin{array}{l}\text { Pancreatic lipase- } \\
\text { related protein } 2\end{array}$ & 527 & 51947 & secreted & $\begin{array}{c}\text { lipid metabolism and } \\
\text { degradation }\end{array}$ & 173 \\
\hline 96. & Q8NG07 & PNMA1 & $\begin{array}{c}\text { Paraneoplastic antigen } \\
\text { Ma1 }\end{array}$ & 478 & 39761 & $\begin{array}{l}\text { nucleus and } \\
\text { cytoplasmic in } \\
\text { tumor cells }\end{array}$ & paraneoplastic antigen & 408 \\
\hline 97. & 015018 & PDZD2 & $\begin{array}{l}\text { PDZ domain- } \\
\text { containing protein* }\end{array}$ & 818 & 280092 & $\begin{array}{l}\text { nucleus } \\
\text { cytoplasm and } \\
\text { endoplasmic } \\
\text { reticulum }\end{array}$ & cell adhesion & 381 \\
\hline 98. & 095613 & PCNT & Pericentrin* & 540 & 378037 & cytoplasm & protein binding & 447 \\
\hline 99. & Q5VV67 & PPRC1 & $\begin{array}{c}\text { Peroxisome } \\
\text { proliferator-activated } \\
\text { receptor gamma } \\
\text { coactivator-related } \\
\text { protein } 1 *\end{array}$ & 611 & 177544 & nucleus & $\begin{array}{l}\text { acts as a coactivator } \\
\text { during transcriptional } \\
\text { activation of nuclear } \\
\text { genes related to } \\
\text { mitochondrial } \\
\text { biogenesis and cell } \\
\text { growth }\end{array}$ & 176 \\
\hline 100. & 000541 & PES1 & Pescadillo homolog 1 & 693 & 68003 & nucleus & $\begin{array}{l}\text { ribosome biogenesis } \\
\text { and rRNA processing }\end{array}$ & 189 \\
\hline 101. & P15259 & PGAM2 & $\begin{array}{c}\text { Phosphoglycerate } \\
\text { mutase }\end{array}$ & 899 & 28766 & $\begin{array}{l}\text { nucleus } \\
\text { cytosol }\end{array}$ & $\begin{array}{l}\text { involved in glycolysis } \\
\text { and gluconeogenesis }\end{array}$ & 316 \\
\hline 102. & P16284 & PECAM1 & $\begin{array}{l}\text { Platelet endothelial cell } \\
\text { adesion molecular }\end{array}$ & 655 & 82536 & cell membrane & protein binding & 399 \\
\hline 103. & Q9HAU0 & PLEKHA5 & $\begin{array}{l}\text { Pleckstrin homology } \\
\text { domain-containing } \\
\text { family A member 5* }\end{array}$ & 720 & 127464 & cytoplasm & protein binding & 294 \\
\hline 104. & Q15149 & PLEC & Plectin* & 574 & 531791 & cytoplasm & $\begin{array}{l}\text { ankyrin binding and } \\
\text { apotoptic process }\end{array}$ & 258 \\
\hline \multirow[t]{2}{*}{105.} & Q9NS40 & KCNH7 & $\begin{array}{l}\text { Potassium voltage- } \\
\text { gated channel } \\
\text { subfamily } \mathbf{H} \\
\text { member } 7^{*}\end{array}$ & 757 & 135000 & membrane & $\begin{array}{l}\text { pore-forming (alpha) } \\
\text { subunit of voltage- } \\
\text { gated potassium } \\
\text { channel }\end{array}$ & 067 \\
\hline & & & & & & & & (Continued) \\
\hline
\end{tabular}




\begin{tabular}{|c|c|c|c|c|c|c|c|c|}
\hline & $\begin{array}{l}\text { Accession } \\
\text { Number }^{\text {b }}\end{array}$ & Gene Name ${ }^{b}$ & Protein Name ${ }^{b}$ & $\mathbf{I P}^{\mathbf{c}}$ & $\operatorname{MW}(\mathbf{D a})^{\mathrm{c}}$ & Location $^{\text {b }}$ & $\begin{array}{c}\text { Biological Processes } \\
\text { and Molecular } \\
\text { Function }^{b}\end{array}$ & $\begin{array}{c}\text { Quantification } \\
\text { 117:115 }^{\mathrm{a}}\end{array}$ \\
\hline 106. & Q7L014 & DDX46 & $\begin{array}{l}\text { Probable ATP- } \\
\text { dependent RNA } \\
\text { helicase DDX46 }\end{array}$ & 933 & 117362 & nucleus & $\begin{array}{l}\text { nucleoside nucleotide } \\
\text { and nucleic acid } \\
\text { metabolism }\end{array}$ & 178 \\
\hline 107. & Q7Z7M1 & ADGRD2 & $\begin{array}{l}\text { Probable G-protein } \\
\text { coupled receptor } 144^{*}\end{array}$ & 833 & 104087 & cell membrane & $\begin{array}{l}\text { G-protein coupled } \\
\text { receptor transducer }\end{array}$ & 681 \\
\hline 108. & P35232 & PHB & Prohibitin & 557 & 29804 & $\begin{array}{c}\text { Membrane } \\
\text { and cytoplasm }\end{array}$ & $\begin{array}{l}\text { DNA replication cell } \\
\text { proliferation and } \\
\text { differentiation proto- } \\
\text { oncogene }\end{array}$ & 347 \\
\hline 109. & P27918 & CFP & properdin & 833 & 51276 & Secreted & immunity and defense & 497 \\
\hline 110. & Q13258 & PTGDR & $\begin{array}{l}\text { Prostaglandin D2 } \\
\text { receptor* }\end{array}$ & 939 & 40271 & cell membrane & $\begin{array}{c}\text { receptor for } \\
\text { prostaglandin D2 }\end{array}$ & 282 \\
\hline 111. & Q9P2B2 & PTGFRN & $\begin{array}{l}\text { Prostaglandin F2 } \\
\text { receptor negative } \\
\text { regulator* }\end{array}$ & 616 & 98556 & $\begin{array}{l}\text { endoplasmic } \\
\text { reticulum } \\
\text { membrane }\end{array}$ & protein binding & 213 \\
\hline 112. & P14921 & ETS1 & Protein C-ets-1* & 503 & 50408 & $\begin{array}{l}\text { nucleus and } \\
\text { cytoplasm }\end{array}$ & transcription factor & 352 \\
\hline 113. & P80511 & S100A12 & Protein S100-A12* & 581 & 10575 & $\begin{array}{l}\text { Cytoplasm and } \\
\text { cell membrane }\end{array}$ & $\begin{array}{l}\text { signal transduction } \\
\text { inflammatory } \\
\text { processes and immune } \\
\text { response }\end{array}$ & 341 \\
\hline 114. & A3KN83 & SBNO1 & $\begin{array}{c}\text { Protein strawberry } \\
\text { notch homolog } 1^{*}\end{array}$ & 796 & 154312 & nucleus & $\begin{array}{l}\text { regulation of } \\
\text { transcription }\end{array}$ & 412 \\
\hline 115. & Q13882 & PTK6 & $\begin{array}{c}\text { Protein-tyrosine } \\
\text { kinase } 6^{*}\end{array}$ & 656 & 51834 & $\begin{array}{l}\text { cytoplasm and } \\
\text { nucleus }\end{array}$ & $\begin{array}{l}\text { involved in protein } \\
\text { metabolism and } \\
\text { modification } \\
\text { implicated in the } \\
\text { regulation of a variety } \\
\text { of signaling pathways } \\
\text { that control the } \\
\text { differentiation and } \\
\text { maintenance of normal } \\
\text { epithelia as well as } \\
\text { tumor growth }\end{array}$ & 479 \\
\hline 116. & Q9Y315 & DERA & $\begin{array}{l}\text { Putative deoxyribose- } \\
\text { phosphate aldolase * }\end{array}$ & 908 & 35231 & cytoplasm & lyase & 189 \\
\hline 117. & Q15311 & RALBP1 & $\begin{array}{l}\text { RalA-binding protein } \\
1 *\end{array}$ & 568 & 76063 & membrane & $\begin{array}{l}\text { signal transduction and } \\
\text { ATP catabolic process }\end{array}$ & 213 \\
\hline 118. & Q08999 & RBL2 & $\begin{array}{c}\text { Retinoblastoma-like } \\
\text { protein } 2 *\end{array}$ & 727 & 128367 & nucleus & transcription factor & 338 \\
\hline 119. & Q7Z5J4 & RAI1 & $\begin{array}{c}\text { Retinoid-acid induced } \\
\text { protein } 1 *\end{array}$ & 903 & 203352 & $\begin{array}{l}\text { cytoplasm and } \\
\text { nucleus }\end{array}$ & $\begin{array}{l}\text { transcriptional } \\
\text { regulator }\end{array}$ & 229 \\
\hline 120. & Q5T5U3 & ARHGAP21 & $\begin{array}{c}\text { Rho GTPase-activating } \\
\text { protein } 21\end{array}$ & 785 & 217331 & $\begin{array}{l}\text { peripheral } \\
\text { membrane } \\
\text { protein }\end{array}$ & $\begin{array}{l}\text { GTPase-activating } \\
\text { protein }\end{array}$ & 248 \\
\hline 121. & Q9BST9 & RTKN & Rhotekin & 718 & 62667 & nucleoplasm & $\begin{array}{c}\text { mediates Rho } \\
\text { signaling to activate } \\
\text { NF-kappa-B and } \\
\text { increases resistance to } \\
\text { apoptosis }\end{array}$ & 276 \\
\hline
\end{tabular}




\begin{tabular}{|c|c|c|c|c|c|c|c|c|}
\hline & $\begin{array}{l}\text { Accession } \\
\text { Number }\end{array}$ & Gene Name ${ }^{b}$ & Protein Name ${ }^{b}$ & $\mathbf{I P}^{\mathbf{c}}$ & $\operatorname{MW}(\mathbf{D a})^{\mathrm{c}}$ & Location $^{b}$ & $\begin{array}{c}\text { Biological Processes } \\
\text { and Molecular } \\
\text { Function }^{\mathrm{b}}\end{array}$ & $\begin{array}{c}\text { Quantification } \\
117: 115^{\mathrm{a}}\end{array}$ \\
\hline 122. & Q14137 & BOP1 & $\begin{array}{c}\text { Ribosome biogenesis } \\
\text { protein BOP1 }\end{array}$ & 580 & 83630 & nucleus & $\begin{array}{l}\text { ribosome biogenesis, } \\
\text { rRNA processing }\end{array}$ & 489 \\
\hline 123. & Q9H7B2 & RPF2 & $\begin{array}{l}\text { Ribosome production } \\
\text { factor } 2 \text { homolog* }\end{array}$ & 1000 & 35583 & nucleus & poly(A) RNA binding & 451 \\
\hline 124. & Q8WV20 & RBMS1 & $\begin{array}{l}\text { RNA binding motif } \\
\text { single stranded } \\
\text { interacting protein } 1\end{array}$ & 891 & 44505 & nucleus & $\begin{array}{c}\text { nucleoside nucleotide } \\
\text { and nucleic acid } \\
\text { metabolism }\end{array}$ & 607 \\
\hline 125. & P21817 & RYR1 & Ryanodine receptor $1 *$ & 518 & 565176 & $\begin{array}{l}\text { sarcoplasmic } \\
\text { reticulum } \\
\text { membrane }\end{array}$ & calcium transport & 484 \\
\hline 126. & 014641 & DVL2 & $\begin{array}{l}\text { Segment polarity } \\
\text { protein dishevelled } \\
\text { homolog DVL-2* }\end{array}$ & 567 & 78948 & $\begin{array}{l}\text { cell membrane } \\
\text { and cytoplasm }\end{array}$ & Wnt signaling pathway & 379 \\
\hline 127. & Q99719 & SEPT5 & Septin-5 & 621 & 42777 & cytoplasm & $\begin{array}{l}\text { GTO and protein } \\
\text { binding }\end{array}$ & 249 \\
\hline 128. & Q9UQ35 & SRRM2 & $\begin{array}{l}\text { Serine/arginine } \\
\text { repetitive matrix } \\
\text { protein } 2^{*}\end{array}$ & 1205 & 299615 & nucleus & $\begin{array}{l}\text { pre-mRNA processing } \\
\text { and mRNA splicing }\end{array}$ & 237 \\
\hline 129. & P15056 & BRAF & $\begin{array}{c}\text { Serine/Threonine } \\
\text { protein kinase B-raf* }\end{array}$ & 729 & 84437 & $\begin{array}{l}\text { nucleus and } \\
\text { cytoplasm }\end{array}$ & proto-oncogene & 394 \\
\hline 130. & Q06190 & PPP2R3A & $\begin{array}{l}\text { Serine/threonine- } \\
\text { protein phosphatase } 2 \mathrm{~A} \\
\text { regulatory subunit B" } \\
\text { subunit alpha }\end{array}$ & 509 & 130278 & $\begin{array}{c}\text { Colocalized } \\
\text { with protein } \\
\text { phosphatase } \\
\text { type } 2 \mathrm{~A} \\
\text { complex }\end{array}$ & $\begin{array}{l}\text { calcium ion and } \\
\text { protein binding and } \\
\text { regulator of Wnt } \\
\text { signaling pathway }\end{array}$ & 290 \\
\hline 131. & P42345 & MTOR & $\begin{array}{c}\text { Serine/threonine- } \\
\text { protein kinase mTOR* }\end{array}$ & 673 & 288892 & ubiquitous & $\begin{array}{l}\text { it is a central regulator } \\
\text { of cellular metabolism } \\
\text { growth and survival in } \\
\text { response to hormones } \\
\text { growth factors } \\
\text { nutrients energy and } \\
\text { stress signals }\end{array}$ & 257 \\
\hline 132. & Q96Q15 & SMG1 & $\begin{array}{c}\text { Serine/threonine- } \\
\text { protein kinase SMG1* }\end{array}$ & 603 & 410501 & $\begin{array}{c}\text { nucleus and } \\
\text { cytoplasm }\end{array}$ & $\begin{array}{l}\text { kinase involved in } \\
\text { mRNA surveillance } \\
\text { and genotoxic stress } \\
\text { response pathways }\end{array}$ & 379 \\
\hline 133. & Q15464 & SHB & $\begin{array}{l}\text { SH2 domain-containig } \\
\text { adapter protein B }\end{array}$ & 910 & 55042 & cytoplasm & $\begin{array}{l}\text { involved in } \\
\text { angiogenesis and } \\
\text { apoptosis }\end{array}$ & 225 \\
\hline 134. & Q9H1V8 & SLC6A17 & $\begin{array}{c}\text { Sodium-dependent } \\
\text { neutral amino acid } \\
\text { transporter SLC6A17 }\end{array}$ & 568 & 81001 & $\begin{array}{l}\text { cytoplasmic } \\
\text { vesicle } \\
\text { multi-pass } \\
\text { membrane } \\
\text { protein }\end{array}$ & $\begin{array}{l}\text { neurotransmitter } \\
\text { transporter }\end{array}$ & 201 \\
\hline 135. & Q96BI1 & SLC22A18 & $\begin{array}{c}\text { Solute Carrier Family } \\
22 \text { member } 18\end{array}$ & 662 & 13354 & cell membrane & zinc ion binding & 236 \\
\hline 136. & 094956 & SLCO2B1 & $\begin{array}{c}\text { Solute carrier organic } \\
\text { anion transporter } \\
\text { family member } 2 \mathrm{~B} 1 *\end{array}$ & 870 & 76711 & cell membrane & ion transport & 171 \\
\hline
\end{tabular}




\begin{tabular}{|c|c|c|c|c|c|c|c|c|}
\hline & $\begin{array}{l}\text { Accession } \\
\text { Number }^{b}\end{array}$ & Gene Name ${ }^{b}$ & Protein Name $^{b}$ & $\mathbf{I P}^{\mathbf{c}}$ & $\operatorname{MW}(\mathbf{D a})^{\mathbf{c}}$ & Location $^{\text {b }}$ & $\begin{array}{c}\text { Biological Processes } \\
\text { and Molecular } \\
\text { Function }^{\mathrm{b}}\end{array}$ & $\begin{array}{c}\text { Quantification } \\
117: 115^{\mathrm{a}}\end{array}$ \\
\hline 137. & P11277 & SPTB & $\begin{array}{l}\text { Spectrin beta chain } \\
\text { erythrocytic* }\end{array}$ & 515 & 246468 & cytoplasm & $\begin{array}{l}\text { cell structure and } \\
\text { motility }\end{array}$ & 127 \\
\hline 138. & Q9BPZ7 & МАРКАР1 & $\begin{array}{c}\text { Stress-activated map } \\
\text { kinase interacting } \\
\text { protein } 1\end{array}$ & 724 & 59123 & $\begin{array}{l}\text { cell membrane } \\
\text { and nucleus }\end{array}$ & $\begin{array}{l}\text { stress response and } \\
\text { phosphatidic acid } \\
\text { binding }\end{array}$ & 463 \\
\hline 139. & Q15431 & SYCP1 & $\begin{array}{c}\text { Synaptonemal complex } \\
\text { protein } 1^{*}\end{array}$ & 578 & 114192 & $\begin{array}{l}\text { Nucleus and } \\
\text { chromosome }\end{array}$ & cell cycle and meiosis & 342 \\
\hline 140. & Q9BQ70 & TCF25 & $\begin{array}{l}\text { Transcription } \\
\text { factor } 25^{*}\end{array}$ & 595 & 76667 & nucleus & $\begin{array}{l}\text { transcriptional } \\
\text { repressor }\end{array}$ & 406 \\
\hline 141. & Q01664 & TFAP4 & $\begin{array}{c}\text { Transcription factor } \\
\text { AP-4 }\end{array}$ & 563 & 38726 & nucleus & transcription regulator & 348 \\
\hline 142. & Q8NHW3 & MAFA & $\begin{array}{l}\text { Transcription factor } \\
\text { mammalian MafA* }\end{array}$ & 749 & 36982 & nucleus & transcriptional factor & 941 \\
\hline 143. & Q8NEM7 & SUPT20H & $\begin{array}{l}\text { Transcription factor } \\
\text { SPT20 homolog }\end{array}$ & 877 & 85789 & nucleus & $\begin{array}{l}\text { required for MAP } \\
\text { kinase p38 (MAPK11 } \\
\text { MAPK12 MAPK13 } \\
\text { and/or MAPK14) }\end{array}$ & 421 \\
\hline 144. & P29084 & GTF2E2 & $\begin{array}{l}\text { Transcription initiation } \\
\text { factor IIE subunit beta }\end{array}$ & 966 & 33044 & nucleus & $\begin{array}{l}\text { basal transcription } \\
\text { factor }\end{array}$ & 227 \\
\hline 145. & 075410 & TACC1 & $\begin{array}{c}\text { Transforming acidic } \\
\text { coiled-coil-containing } \\
\text { protein } 1^{*}\end{array}$ & 481 & 87794 & $\begin{array}{l}\text { cytoplasm and } \\
\text { nucleus }\end{array}$ & cell cycle and division & 555 \\
\hline 146. & Q01995 & TAGLN & Transgelin* & 887 & 22611 & cytoplasm & muscle protein & 099 \\
\hline 147. & Q9UJA5 & TRTM6 & $\begin{array}{c}\text { tRNA } \\
\text { (adenine(58)-N(1))- } \\
\text { methyltransferase } \\
\text { non-catalytic subunit } \\
\text { TRM6 }\end{array}$ & 718 & 55799 & nucleus & tRNA processing & 205 \\
\hline 148. & Q9NYL9 & TMOD3 & Tropomodulin-3 & 508 & 39595 & cytoplasm & $\begin{array}{l}\text { blocks the elongation } \\
\text { and de-polymerization } \\
\text { of the actin filaments }\end{array}$ & 122 \\
\hline 149. & P06753 & ТPM3 & $\begin{array}{c}\text { Tropomyosin alpha-3- } \\
\text { chain }\end{array}$ & 468 & 32950 & $\begin{array}{l}\text { cytoplasm and } \\
\text { cytoskeleton }\end{array}$ & muscle protein & 294 \\
\hline 150. & P07951 & TPM2 & $\begin{array}{c}\text { Tropomyosin beta } \\
\text { chain }\end{array}$ & 466 & 32851 & $\begin{array}{l}\text { cytoplasm and } \\
\text { cytoskeleton }\end{array}$ & muscle protein & 067 \\
\hline 151. & P49815 & TSC2 & Tuberin* & 698 & 200608 & cytoplasm & $\begin{array}{l}\text { tumor suppressor and } \\
\text { intracellular protein } \\
\text { traffic }\end{array}$ & 401 \\
\hline 152. & P07437 & TUBB & Tubulin beta chain* & 478 & 49671 & $\begin{array}{l}\text { cytoplasm and } \\
\text { cytoskeleton }\end{array}$ & $\begin{array}{l}\text { protein binding and } \\
\text { structural constituent } \\
\text { of cytoskeleton }\end{array}$ & 435 \\
\hline 153. & P78324 & SIRPA & $\begin{array}{l}\text { Tyrosine-protein } \\
\text { phosphatase non- } \\
\text { receptor type } \\
\text { substrate } 1^{*}\end{array}$ & 651 & 54967 & membrane & $\begin{array}{c}\text { involved in } \\
\text { intracellular signaling } \\
\text { during synaptogenesis } \\
\text { and in synaptic } \\
\text { function }\end{array}$ & 276 \\
\hline 154. & Q9NPG3 & UBN1 & Ubinuclein-1* & 937 & 121520 & $\begin{array}{l}\text { nucleus, cell } \\
\text { junction }\end{array}$ & $\begin{array}{l}\text { novel regulator of } \\
\text { senescence }\end{array}$ & 262 \\
\hline
\end{tabular}

(Continued) 


\begin{tabular}{|c|c|c|c|c|c|c|c|c|}
\hline & $\begin{array}{l}\text { Accession } \\
\text { Number }^{b}\end{array}$ & Gene Name ${ }^{b}$ & Protein Name ${ }^{b}$ & $I^{c}$ & $\operatorname{MW}(\mathbf{D a})^{\mathrm{c}}$ & Location $^{b}$ & $\begin{array}{c}\text { Biological Processes } \\
\text { and Molecular } \\
\text { Function }^{b}\end{array}$ & $\begin{array}{c}\text { Quantification } \\
117: 115^{\mathrm{a}}\end{array}$ \\
\hline 155. & Q14139 & UBE4A & $\begin{array}{l}\text { Ubiquitin conjugation } \\
\text { factor } \mathrm{E} 4 \mathrm{~A}^{*}\end{array}$ & 511 & 123522 & cytoplasm & $\begin{array}{l}\text { protein metabolism } \\
\text { and modification }\end{array}$ & 261 \\
\hline 156. & Q9Y6A4 & CFAP20 & $\begin{array}{l}\text { Cilia- and flagella- } \\
\text { associated protein } 20 *\end{array}$ & 978 & 22774 & nucleus & transcription factor & 093 \\
\hline 157. & Q15849 & SLC14A2 & Urea transporter $2 *$ & 651 & 101209 & cell membrane & transport protein & 127 \\
\hline 158. & Q8N6Y0 & USHBP1 & $\begin{array}{c}\text { Usher syndrome type- } \\
\text { 1C protein-binding } \\
\text { protein } 1\end{array}$ & 558 & 76068 & $\begin{array}{l}\text { cytoplasm } \\
\text { nucleus } \\
\text { plasma } \\
\text { membrane }\end{array}$ & signal transduction & 169 \\
\hline 159. & P62955 & CACNG7 & $\begin{array}{l}\text { Voltage-dependent } \\
\text { calcium channel } \\
\text { gamma } 7 \text { subunit }\end{array}$ & 665 & 31003 & membrane & calcium transport & 346 \\
\hline 160. & P21281 & ATP6V1B2 & $\begin{array}{l}\text { V-type proton ATPase } \\
\text { subunit B brain } \\
\text { isoform }\end{array}$ & 557 & 56501 & $\begin{array}{l}\text { peripheral } \\
\text { membrane } \\
\text { protein }\end{array}$ & cation transport & 148 \\
\hline 161. & Q9UJW8 & ZNF180 & $\begin{array}{c}\text { Zinc finger protein } 180 \\
\text { (HHZ168)* }\end{array}$ & 804 & 79111 & nucleus & $\begin{array}{l}\text { involved in } \\
\text { transcriptional } \\
\text { regulation }\end{array}$ & 193 \\
\hline 162. & Q7Z3V5 & ZNF571 & $\begin{array}{l}\text { Zinc finger protein } \\
\text { 571* }\end{array}$ & 871 & 70792 & nucleus & $\begin{array}{l}\text { involved in } \\
\text { transcriptional } \\
\text { regulation }\end{array}$ & 354 \\
\hline 163. & Q9H582 & ZNF644 & Zinc finger protein 644 & 843 & 149565 & nucleus & $\begin{array}{l}\text { involved in } \\
\text { transcriptional } \\
\text { regulation }\end{array}$ & 369 \\
\hline 164. & Q15776 & ZKSCANS & $\begin{array}{c}\text { Zinc finger protein } \\
\text { with KRAB and SCAN } \\
\text { domains } 8\end{array}$ & 704 & 65816 & nucleus & transcription factor & 312 \\
\hline
\end{tabular}

${ }^{a}$ The identification and quantitation of proteins were performed using the Protein Pilot Paragon Method The MS/MS data were processed using a mass tolerance of $10 \mathrm{ppm}$ and $02 \mathrm{Da}$ for the precursor and fragment ions respectively ${ }^{\mathrm{b}} \mathrm{According}$ to "UniProtKB" (http://wwwuniprotorg/) cAccording to "Compute pI/MW" (http://webexpasyorg/compute_pi/) *Proteins involved in epithelial neoplasia ( $\mathrm{p}$-value $=362 \mathrm{E}-05$ ).

samples from benign prostate hyperplasia (BPH) and $\mathrm{PCa}$ patients proving a significant up-regulation of prohibitin in tumoral samples. A significant alteration change was observed in the expression of Actin and microtubule Cytoskeleton proteins (Table 1 - rows 3, 37, 38, 39, 63, $81,82,83,137,146,149,150)$. These proteins are able to organize the cytoplasmic organelles and the intracellular compartments in order to drive the chromosomal separation and the cell division during morphogenesis, cell cycle, and to generate forces during cell migration $[28,29]$. Myosin filaments (Table 1, rows 81, 82, 83, $149,150)$ determine cell surface contractions and muscle cell contraction in accordance with actin. The kinesin (Table 1 , rows 64,65 ) and dynein (Table 1 , rows 37 , 38) proteins carry numerous cellular function including the transport of vesicles and organelles within cells, the beating of flagella and cilia and within the mitotic and meiotic spindles to segregate replicated chromosomes. Within this protein family, kinesin ensures a crucial role in the occurrence and development of human cancer. A great number of proteins from the kinesin super-family show abnormal over-expression in various cancer cells and this expression level indicates as prognostic marker for breast and lung cancer [30, 31]. A change of expression of the members of the $G$ protein coupled receptor proteins is evident (GPRs, Table 1 rows 42, 107,110 ). The GPRs belong to a family of cell-surface molecules implicated in signal transmission. GPRs proteins are implicated in many biological process as cell proliferation, motility, angiogenesis and metastasis and it has been recently highlighted the they are over expressed in various cancer type and have an incisive role to tumor cell growth [32]. The upregulated activity of GPRs might contribute to transition from hormone dependent to hormone independent tumor for prostate and breast cancer. Marinissen et al., [33] suggested that in PCa cell, GPRs can stimulate ERK phosphorylation and increase the transcription of ARs. The observed over 
regulation of kinases (Table 1 , rows 26, 56, 59, 78, 79, $115,129,131,132,138)$ is fully in accordance with the data reported $[34,35]$. In particular an oncogenic role was indicated for the non-receptor type tyrosine kinase, Protein Tyrosine Kinase 6 (PTK6, Table 1 row 115) [36]. PTK6 promotes cancer cell proliferation, migration and survival through activating oncogenic signalling pathways. Moreover it is involved in the activation of signal transducers and activators of transcription (STATs) that control tumorigenesis [37] and promotes AKT activation and phosphorylation [38]. Zheng et al. have described the increased levels of PTK6 mRNA in prostate cancer with respect to healthy normal prostate tissue and normal tissue adjacent to the tumor [39]. The same authors evidenced an higher expression of PTK6 in metastatic human prostate cancer samples, suggesting an oncogenic role for PTK6 in prostate tumor development and metastasis [40].

\section{Pathway and network analyses}

Proteomic data were analyzed using IPA software to select protein involved in cancer development, occurrence or progression and to evidence the biological processes in which these proteins are involved. IPA analysis suggests five Top Networks (Supporting Information, Table S3), the first one related to "Cell Death and Survival, Cancer" comprises 70 focus molecules and evidences as the majority of identified protein are directly and not mainly involved in three signalling pathways that play a crucial role in cancerogenesis: (i) the extracellular signal-regulated kinase (ERK) signaling pathway, (ii) the Nuclear factor kappa B (NF-kB) pathway and (iii) phosphatidylinositol 3-kinase/protein kinase-B/ mammalian target of rapamycin (PI3K/AKT/mTOR) signalling cascade (Figure 3 ).
The extracellular signal-regulated kinase (ERK) signalling pathway controls a broad range of cellular activities such as proliferation, survival, differentiation and motility. ERK regulates chromatin remodelling through the phosphorylation of cytoplasmic and nuclear targets as transcriptional factors and Cytoskeleton proteins [41]. In addition, activation of ERK $1 / 2$ due to radiation, osmotic stress or tumor necrosis factor (TNF) inhibits apoptosis, while inhibition of the same pathway supports apoptosis. It has been shown that the increased activity of extracellular signal-regulated kinase is implicated in the development and prognosis of PCa [42]. Nuclear factor kappa B (NF- $\mathrm{B})$ transcription factors regulate several important physiological processes, including inflammation and immune responses, cell growth, apoptosis, and the expression of certain viral genes. The NF- $\kappa$ B pathway is often active and plays a key role in the disease since it involves a sequence of transcription factors that stimulate promotion and progression of tumors as well as chemotherapy and radiotherapy resistance [43] and it is clear that modulators of this pathway can act at several levels [44]. The phosphatidylinositol 3-kinase/protein kinase-B/mammalian target of rapamycin (PI3K/AKT/ mTOR) signalling cascade is a key oncogenic signalling pathway, which has a central role in several cellular processes significant for cancer progression [45]. The $\mathrm{PI} 3 \mathrm{~K}-\mathrm{AKT}$ pathway is inappropriately activated in many cancers by receptor tyrosine kinases. PI3K/AKT/mTOR pathway prevents apoptosis, induce cancer cell growth and promotes resistance to anticancer therapies acting on cellular differentiation and metabolism $[46,47]$. Recently, several researches have demonstrated that the activation of the PI3K/AKT/mTOR pathway was strongly implicated in the prostate cancer progression [48]. Moreover, Gao et al. suggested that this signalling pathway could serve as a novel target for therapeutic intervention in prostate cancer [49].

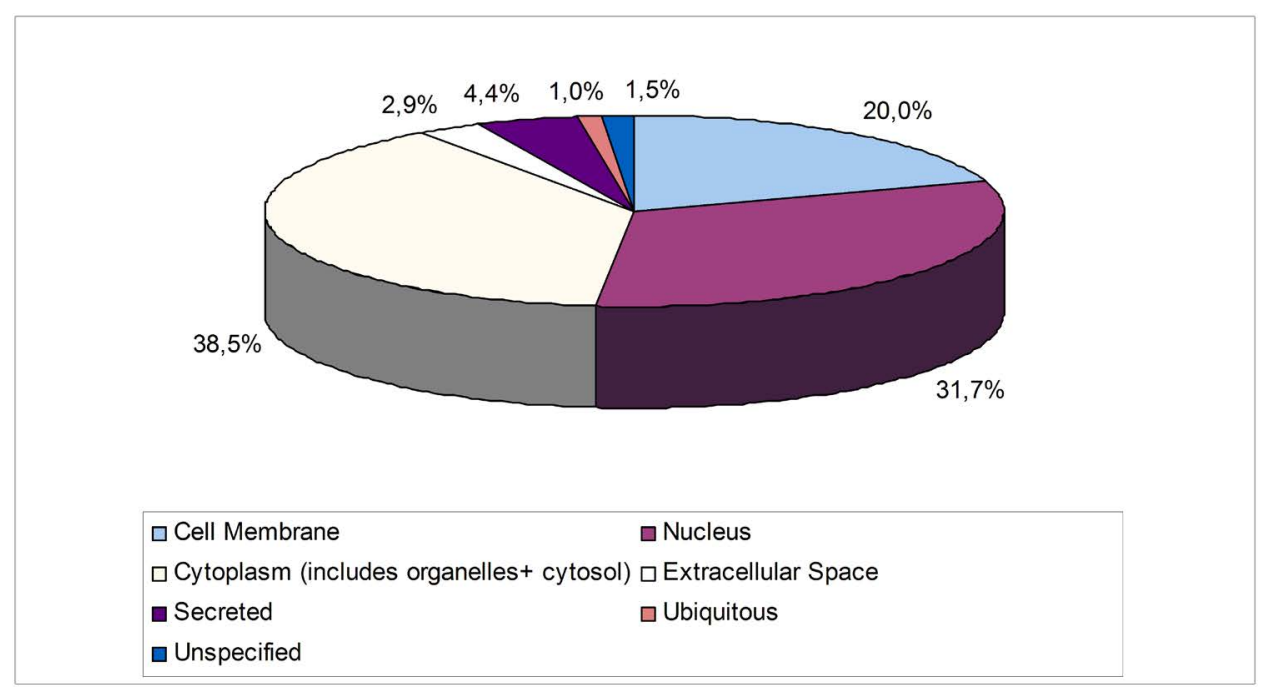

Figure 2: Functional distribution of the identified proteins in accordance to their cellular location. 


\section{PCa differentially expressed proteins vs bodily fluids}

Proteomic data were further elaborated by IPA in order to maximize the impact of the information, to get a more comprehensive understanding about the obtained results and suggest the proposal of biomarkers to screening populations at risk for cancer. The device "Biomarker Filter" measures whether a particular protein is detectable in tissue or bodily fluids in an effort to identify a cohort of possible proteins associated with a specific disease. The proteomic data are evaluated by three restriction levels: (i) Urine, (ii) Urine and Prostate Gland, (iii) Urine, Prostate Gland and Plasma/Serum. Eleven up- and downregulated proteins are selected and reported in Table 2. These 11 proteins are eligible cancer biomarkers and are also present in a set of bodily fluids. In PCa Catenin Beta 1 (CTNNB1, Table 2) contributes to cadherin-mediated adhesion and acts as coactivator binding androgen receptor suggesting that it has a role in castration-resistant disease [50]. An abnormal activation of WNT/ $\beta$-catenin signalling has been reported in colon cancer [51], and a typical upregulation of cytoplasmic $\beta$-catenin was detected in thyroid carcinogenesis [52]. The observed down-regulation of Tropomyosin 2 (TPM2, Table 2) is in agreement with several studies that proved the association of its altered expression with carcinogenesis [53]. The expression change of TPM isoforms can be induced by variety of carcinogens including chemical carcinogens, UV radiation, DNA and RNA tumor viruses during cancer cell transformation. Varisli showed that the expression of TPM2 may decrease with growing score of cancer and suggested the level of this protein are useful as a prognostic biomarker tool for prostate cancer [54]. The up regulation of tropomyosin alpha-3-chain (TPM3, Table 2) is supported by the results of Franzen et al. in which they have found higher level of TPM isoform in the primary breast cancer that had metastasised, rather than in the axillary lymph nodes [55].



Figure 3: "Cell Death and Survival, Cancer, Gastrointestinal disease" network of 70 proteins observed de-regulated in tumoral prostate tissue by the iterative Ingenuity Pathway Analysis software program. The node and edge represent the proteins and their interactions, respectively, while the intensity of the node color indicates degree of up- (red) or down- (green) regulation. 
Table 2: Proteins from prostatic gland that are also present in bodily fluids ${ }^{a}$

\begin{tabular}{|c|c|c|c|c|c|c|c|c|c|}
\hline $\begin{array}{l}\text { Gene } \\
\text { Name }^{(a)}\end{array}$ & $\begin{array}{c}\text { Accession } \\
\mathbf{N}^{(\mathbf{b})}\end{array}$ & Entrez Gene Name & Location & Family & $\begin{array}{c}\text { Fold } \\
\text { Change }\end{array}$ & Blood & $\begin{array}{l}\text { Plasma/ } \\
\text { Serum }\end{array}$ & Urine & $\begin{array}{c}\text { Prostate } \\
\text { Gland }\end{array}$ \\
\hline BRAF & P15056 & $\begin{array}{l}\text { v-raf murine sarcoma viral } \\
\text { oncogene homolog } \mathrm{B}^{(\mathrm{e})}\end{array}$ & Cytoplasm & kinase & 394 & $\mathrm{x}$ & $\mathrm{x}$ & & $\mathrm{x}$ \\
\hline DPYS & Q14117 & Dihydropyrimidinase ${ }^{(c)}$ & Cytoplasm & enzyme & 6304 & & & $\mathrm{x}$ & \\
\hline CTNNB1 & P35222 & $\begin{array}{c}\text { catenin (cadherin- } \\
\text { associated protein) beta } 1 \\
88 \mathrm{kDa}^{(\mathrm{e})}\end{array}$ & Nucleus & $\begin{array}{l}\text { transcription } \\
\text { regulator }\end{array}$ & 2112 & $\mathrm{x}$ & & & $\mathrm{x}$ \\
\hline IGFBP5 & P24593 & $\begin{array}{l}\text { insulin-like growth factor } \\
\text { binding protein } 5^{\text {(d) }}\end{array}$ & $\begin{array}{l}\text { Extracellular } \\
\text { Space }\end{array}$ & other & 3065 & & & $\mathrm{x}$ & $\mathrm{x}$ \\
\hline MTOR & P42345 & $\begin{array}{l}\text { mechanistic target of } \\
\text { rapamycin (serine/ } \\
\text { threonine kinase) }^{(\mathrm{e})}\end{array}$ & Nucleus & kinase & 257 & $\mathrm{x}$ & $\mathrm{x}$ & & $\mathrm{x}$ \\
\hline PGAM2 & P15259 & $\begin{array}{c}\text { phosphoglycerate } \\
\text { mutase } 2^{\text {(d) }}\end{array}$ & Cytoplasm & phosphatase & 316 & & & $\mathrm{x}$ & $\mathrm{x}$ \\
\hline PECAM1 & P16284 & $\begin{array}{l}\text { platelet/endothelial cell } \\
\text { adhesion molecule } 1^{(\mathrm{cde})}\end{array}$ & $\begin{array}{c}\text { Plasma } \\
\text { Membrane }\end{array}$ & other & 399 & $\mathrm{x}$ & $\mathrm{x}$ & $\mathrm{x}$ & $\mathrm{x}$ \\
\hline TAGLN & Q01995 & Transgelin $(\mathrm{cde})$ & Cytoplasm & other & -1002 & & & $\mathrm{x}$ & $\mathrm{x}$ \\
\hline ТРМ3 & P06753 & $\begin{array}{l}\text { tropomyosin alpha-3- } \\
\text { chain }^{(\mathrm{cd})}\end{array}$ & Cytoplasm & other & 2940 & & & $\mathrm{x}$ & $\mathrm{x}$ \\
\hline TPM2 & P07951 & tropomyosin 2 (beta) ${ }^{(\mathrm{e})}$ & Cytoplasm & other & -1484 & $\mathrm{x}$ & $\mathrm{x}$ & & $\mathrm{x}$ \\
\hline YWHAZ & P63104 & $\begin{array}{c}\text { tyrosine } \\
\text { 3-monooxygenase/ } \\
\text { tryptophan } \\
\text { 5-monooxygenase } \\
\text { activation protein zeta } \\
\text { (cde) }\end{array}$ & Cytoplasm & enzyme & 3806 & $\mathrm{x}$ & & $\mathrm{x}$ & $\mathrm{x}$ \\
\hline
\end{tabular}

(a) According to QUIAGEN 's Ingenuity ${ }^{\circledR}$ Pathway Analysis - Biomarker Filter ${ }^{(b)}$ According to "UniProtKB" (http://wwwuniprotorg/) In the table are listed proteins markers suggested by IPA when Biomarker Filter is restricted to ${ }^{(\mathrm{c})}$ Urine $^{(\mathrm{d})}$ Urine and Prostate Gland ${ }^{(\mathrm{e})}$ Urine Prostate Gland Blood and Plasma/Serum.

Up-regulation of the tyrosine 3-monooxygenase/tryptophan 5 monooxygenase activation protein zeta (YWHAZ, Table 2), a 14-3-3 zeta isoform., belonging to the 14-3-3 protein family, was observed. In humans, 7 different 14 3-3 isoforms have been identified ubiquitously expressed and highly conserved in all eukaryotic organisms [56]. This protein family interact with hundreds of binding partners and is involved in the regulation of vital cellular processes [57]. 14-3-3 protein family was associated with proto-oncogene and oncogene products suggesting a direct contribute to cancer development [58]. Murata et al. [59] analyzed the immunoreactivity of YWHAZ in formalin fixed paraffin embedded sections of benign and tumoral prostate tissue evidencing the protein overexpression in PCa tissue. Platelet endothelial cell adhesion molecule-1 (PECAM-1, Table 2) is a $130 \mathrm{kDa}$ membrane glycoprotein belonging to the immunoglobulin superfamily that is able to mediate both homophilic and heterophilic adhesions. PECAM-1 appears to be involved in a variety of biological functions. [60] Karagianis et al. found the up-regulation of
PECAM-1 of the proteome of endothelial cells, in which PECAM was differentially regulated by an androgenindependent angiogenic response [61]. The down regulation of Transgelin (TAGLN, Table 2), is consistent with several studies which reported significantly lower levels of TAGLN expression in the immortalised human prostate epithelial cell line RWPE-1, in the metastatic LNCaP cells and in the metastatic PC3 [62]. The down regulation of transgelin can be correlated to the prostate cancer progression, it may be used as a marker for cancer in addition to provide a target for novel cancer therapies. Perturbation of PTK signalling by mutations and other genetic alterations results in deregulated kinase activity and malignant transformation. It well know the switch role of the mammalian target of rapamycin, mTOR (Table 2), in regulating life or death signals, between "cell growth cell cycle" and "damaged microtubules". mTOR is emerged as a critical effector in cell-signaling pathways commonly deregulated in human cancers suggesting that mTOR inhibitors may be useful in oncology [63]. BRAF 
is a serine/threonine kinase (Table 2) that is commonly activated by somatic point mutation in human cancer and his activity is also regulated by phosphorylation of residues in the activation segment. Moreover the high frequency of mutations in melanoma and the relative lack of effective therapies suggested that inhibition of BRAF activity may be an important new strategy in the treatment of some cancer types [64]. The upregulation of Dihydropyrimidinase enzyme (DPYS, Table 2) is another important data. DPYS deficiency induces haematological or gastrointestinal toxicity during treatment with 5-fluorouracil for common neoplasms [65]. Pyrimidine pathways are fundamental in human physiology and several studies report their upregulation in malignancy [66] making them ideal targets for pharmacological intervention. Finally, the identification of upregulated insulin-like growth factor binding protein 5 (IGFBP5, Table 2) is in agreement with its role in the IGF system, where is involved in normal growth and development. In particular increased expression of IGFBP5 has been reported in tumors of the gastrointestinal tract [67, 68]. IGFBP5 appears to exert a specific inhibitory effect on melanoma growth and metastasis through inhibition of the ERK1/2 and P38-MAPK pathways, therefore it may qualify as a useful therapeutic target against melanoma and other cancers [67].

The proposed proteomic approach, focused on base-soluble proteins from tissue and present in biological fluids, constitutes a study leading to a deeper understanding of the $\mathrm{PCa}$ from a molecular perspective. The selective proteome extraction allows a direct correlation and identification of deregulated pathways providing a panel of candidate diagnostic biomarkers. A limitation of the study might be the relatively small sample number, but the opportunity to transfer this results on other biological matrices, more easily available (as body fluids), opens new chances. The identification of eleven deregulated proteins from prostatic gland, present in body fluids, and some specific for urine, could be an important start point to select new cancer biomarkers. Further studies are needed to confirm the proposed biomarkers and to evaluate the diagnostic potential of the other differentially expressed proteins which might further improve the diagnostics accuracy of the proposed set.

\section{MATERIALS AND METHODS}

\section{Reagents and chemicals}

Ammonium Bicarbonate $\left(\mathrm{NH}_{4} \mathrm{HCO}_{3}, 99.5 \%\right)$, trypsin (proteomics grade), $\alpha$-cyano-4-hydroxy-transcynnamic acid ( $\alpha$-CHCA, 99,0\%), water (HPLC grade), trifluoracetic acid (TFA, 99,0\%), methanol (HPLC grade), acetone, protease inhibitor cocktail and protein standards for protein molecular weight marker were purchased from Fluka-Sigma Aldrich S.r.l. (Milan, Italy). Protein standards and reagent for protein quantification were acquired by Bio-Rad's Laboratories, Inc. (Monza, Italy). iTRAQ reagents and buffers were obtained from Applied Biosystems (Foster City, CA). Peptide and protein standards, for mass spectrometer external calibration, were prepared from the Sequazime peptide mass standard kit (Applied Biosystems, Framingham, MA, USA).

\section{Protein extraction}

The experimental procedure was developed on porcine prostate tissue. The prostate tissue was given by official slaughterhouse after veterinary inspection and transferred in ice in laboratory. Tissues were washed three times in ice-cold phosphate buffered saline, cut in small pieces, weighed and freezed at $-80^{\circ} \mathrm{C}$ until the protein extraction. The tissues obtained from a total of ten patients (A-L) affected by prostate cancer (Gleason score $6,3+3$ ) with elevated PSA level (between 10 to $19 \mathrm{ng} / \mathrm{ml}$ ), classified by Tumour Node Metastasis (TNM) as T1c, N0, M0, were selected for the study after informed consent. This study was approved by the ethics committee of Magna Graecia University, patients had signed a written consent to prostate biopsies and clinical data access for research purpose. After radical prostatectomy "Non Tumoral" (NT) and "Tumoral" (T) fragments prostate tissue from the same individual were cut in two sections. One section was formalin fixed paraffin embedded and stained with hematoxylin-eosin for histological evaluation while the second one was immediately frozen at $-80^{\circ} \mathrm{C}$ prior to proteins extraction. The frozen prostate tissue were powdered in liquid nitrogen. The powdered tissues were further homogenized in $1 \mathrm{~mL}$ of a cold solution containing 50mM NH $\mathrm{mCO}_{3}(\mathrm{pH} 8), 0,05 \% \mathrm{SDS}(\mathrm{v} / \mathrm{v})$ and protease inhibitor cocktail $(1: 100, \mathrm{v} / \mathrm{v})$, then submitted to sonication conditions 3 times for 10s/time [17, 18]. Each operation was performed on ice. The resulting homogenates were centrifuged at $50,000 \times \mathrm{g}$ for $1 \mathrm{~h}$ at $4{ }^{\circ} \mathrm{C}$. Concentration of protein extracted was determined by Bradford's assay [69].

\section{Immunodepletion of high-abundant proteins}

The porcine proteins extracted were depleted of high abundant proteins using two commercially cartridge: "Multiple affinity removal spin cartridge" (Agilent Technologies, Milan, Italy, 5188-5230) and "ProteoPrep Blu Albumin and IgG depletion Medium" (Sigma Aldrich, PROT-BA). The cartridge were treated three times with $200 \mu \mathrm{l}$ of $50 \mathrm{mM} \mathrm{NH}_{4} \mathrm{HCO}_{3},(\mathrm{pH} 8)$, before loading the sample. A volume of $200 \mu \mathrm{l}$, containing $500 \mu \mathrm{g}$ of extracted proteins, were applied on column and incubated for $10 \mathrm{~min}$ at room temperature. After centrifugation at $3000 \mathrm{rpm}$ for $1 \mathrm{~min}$, the flow-through fraction (depleted of albumin, $\operatorname{IgG}, \operatorname{IgA}$, transferrin, haptoglobin and $\alpha 1$-antitrypsin for Agilent column and of albumin and IgG for Sigma column) were loaded again on column, centrifuged and collected. The cartridges were 
washed two times with $200 \mu \mathrm{l}$ of $50 \mathrm{mM} \mathrm{NH}_{4} \mathrm{HCO}_{3}$ and the relative flow-through were collected and combined with the previous depleted fractions. To elute the membrane-bound high abundant proteins, two washing with $\left(\mathrm{NH}_{4}\right)_{2} \mathrm{CO}_{3}(\mathrm{pH} \mathrm{10})$, were performed. After $10 \mathrm{~min}$ of incubation and a subsequent centrifugation at $3000 \mathrm{rpm}$ for $2 \mathrm{~min}$, the eluted fractions were collected. An aliquot of low abundant proteins fraction and of high abundant eluted proteins were analyzed directly by linear MALDI mass spectrometry and the relative protein amount was quantified by Bradford's assay. Moreover, each fraction eluted was visualized on SDS-PAGE. Depletion of high abundant proteins for human prostate was performed only with Multiple affinity removal spin cartridge.

\section{SDS-page}

Depleted flow-through, eluted fraction containing high abundant proteins and an aliquot of whole extracted proteins were analyzed by SDS-PAGE. All fractions were mixed with $5 \mathrm{x}$ gel loading buffer, containing 2-mercaptoethanol and bromophenol blue, denaturated at $95^{\circ} \mathrm{C}$ for $10 \mathrm{~min}$ before electrophoresis analysis in $12.5 \%$ sodium dodecyl sulphate-polyacrylamide gel electrophoresis (SDS-PAGE). Precision Plus Protein kaleidoscope standard (Bio-Rad's Laboratories, Milan, Italy) was loaded in the molecular weight marker lane for porcine samples, while an homemade protein molecular weight marker (Lactoferrin 87 kDa, L9507; Bovine Serum Albumin $66 \mathrm{kDa}, \mathrm{A} 2153$; Albumin from chicken $44 \mathrm{kDa}$, A5503; Mioglobin from equine skeletal muscle $17 \mathrm{kDa}$, M0630; Cytocrome C $12 \mathrm{kDa}, \mathrm{C} 2506$ ) was adopted for human proteins. Proteins were stained with Comassie Brillant Blu R-250 for 4 hours and destained overnight with a solution containing $40 \% \mathrm{MeOH}, 10 \% \mathrm{CH}_{3} \mathrm{COOH}$ and $50 \% \mathrm{H}_{2} \mathrm{O}$.

\section{Porcine protein digestion}

Fifty micrograms of pig prostatic proteins from the depleted fraction proteins were digested overnight with trypsin, protein to enzyme ratio of $20: 1$, at $37^{\circ} \mathrm{C}$ in $\mathrm{NH}_{4} \mathrm{HCO}_{3}, 50 \mathrm{mM}(\mathrm{pH} 8.0)$ and dried by Concentrator Plus system (Eppendorf, Hamburg, Germany).

\section{Human proteins digestion and iTRAQ sample labelling}

The experimental conditions for i-TRAQ quantitative analysis were modified as follows. The six standard proteins mixture was digested with trypsin (ratio enzyme: substrate, 1:20) in a solution of Tetraethylammonium bromide (TEAB, $0.5 \mathrm{M}$ ) and labelled without alkylation and reduction steps. The resulting peptides mixture was separated by off line RP-HPLC and analysed by MALDI-TOF MS. Approximately $40-60 \%$ of
Six-protein Mix peptides were identified and quantified. 20 peptides of Bovine Serum Albumin (P02769), 23 peptides of $\beta$-Galactosidase (P00722), 2 peptides of $\alpha$-Lactalbumin (P00711), 4 peptides of $\beta$-Lactoglobulin (P02754), 4 peptides of Lysozyme (P00698) and 18 peptides of Apotransferrin (P02787) were identified by MS/MS analysis (Table S1, Supporting Information). The number of identified peptides was satisfactory for the unique protein identification with suitable sequence coverage.

Two hundred micrograms of proteins from immunodepleted fractions were precipitated overnight at $-20^{\circ} \mathrm{C}$ in six volume of cold acetone. The pellet was re-suspended in $30 \mu \mathrm{l}$ of $500 \mathrm{mM}$ triethyl ammonium bicarbonate buffer (TEAB, supplied by Applied Biosystem and named as "Dissolution Buffer") and the proteins were quantified by Bradford's Protein Assay. Ten micrograms of each NT fraction from patients A-L were pooled together and digested with trypsin, protein to enzyme ratio of $20: 1$, at $37^{\circ} \mathrm{C}$ overnight. The same procedure was performed for $\mathrm{T}$ fractions from patients A-L. Tryptic peptides were labelled with the iTRAQ reagents $(\mathrm{m} / \mathrm{z} 115.1$ and 117.1) following the manifacturer's protocol (Applied Biosystem). Briefly, the iTRAQ reagents were thawed at room temperature and spun to collect the reagent at the bottom of the tube and dissolved in $70 \mu \mathrm{L}$ of ethanol. The iTRAQ labels were added to the digested samples, in particular $\mathrm{m} / \mathrm{z} 115.1$ reporter ions was added to NT sample, while $\mathrm{m} / \mathrm{z} 117.1$ to T samples. The mixture was vortexed, centrifuged and incubated for $90 \mathrm{~min}$ on a rocker at 5rpm (Digital Rocker RK-1D, Witeg, Germany). The labelled samples were combined and dried in Concentrator Plus system prior to reverse phase chromatography [70-72] (RP-HPLC) fractionation as reported.

\section{MALDI-TOF MS and MS/MS analysis}

Linear MALDI-TOF spectra were acquired with a 4700 Proteomics Analyzer mass spectrometer from Applied Biosystems (Foster City, CA) equipped with a $200-\mathrm{Hz}$ Nd:YAG laser at 355-nm wavelength. A $1-\mu \mathrm{L}$ portion of a premixed solution of whole or depleted samples and $\alpha$-CHCA $(0.3 \%$ in TFA) was spotted on the matrix target, dried at room temperature, and analyzed in the mass spectrometer. Spectra were acquired averaging 2500 laser shots with a mass accuracy of $500 \mathrm{ppm}$ in default calibration mode that was performed using the following set of standards: insulin (bovine, $[\mathrm{M}+\mathrm{H}]+$ average $\mathrm{m} / \mathrm{z} 5734.59$ ), apomyoglobin (horse, $[\mathrm{M}+\mathrm{H}] 2+$ average $\mathrm{m} / \mathrm{z}$ 8476.78, $[\mathrm{M}+\mathrm{H}]+$ average $\mathrm{m} / \mathrm{z} 16$ 952.56), and thioredoxin (Escherichia coli, [M $+\mathrm{H}]+$ average $\mathrm{m} / \mathrm{z}$ 11 674.48). MS and MS/MS analysis of offline spotted peptide samples were performed using the 5800 MALDITOF/TOF analyzer (AB SCIEX, Darmstadt, Germany) equipped with a neodymium: yttrium-aluminiumgarnet laser (laser wavelength: $349 \mathrm{~nm}$ ), in reflectron 
positive-ion mode. All chromatographic fractions were re-suspended in $10 \mu \mathrm{l}$ of $\alpha$-CHCA matrix $(10 \mathrm{mg} / \mathrm{mL}$, $\mathrm{CH}_{3} \mathrm{CN} / 0,3 \%$ TFA in water, 50:50, v:v), $1 \mu \mathrm{l}$ of peptides matrix mixed solution was spotted on a MALDI plate and dried at room temperature. At least 4,000 laser shots were typically accumulated with a laser pulse rate of 400 $\mathrm{Hz}$ in the MS mode, whereas in the MS/MS mode spectra up to 5,000 laser shots were acquired and averaged with a pulse rate of $1,000 \mathrm{~Hz}$. MS/MS experiments were performed at a collision energy of $1 \mathrm{kV}$ and ambient air was used as the collision gas with a medium pressure of $10^{-6}$ Torr. Protein identification was performed with the Protein Pilot 4.0 software program (AB Sciex) using the Paragon protein database search algorithm (AB Sciex). ${ }^{20}$ The data analysis parameters for porcine samples were: Sample Type: Identification; Cys Alkylation: None; digestion: Trypsin; Instrument: 5800 AB Sciex; Species: Suis Scrofa; Database: SwissProt; Search Effort: Thorought ID; Detected Protein Threshold [unused Protscore (Conf)]:1.5 (95,0\%). For human labelled proteins, the data analysis parameters were as follows: Sample type: iTRAQ 4plex (Peptide Labelled); Cys Alkylation: None; Digestion: Trypsin; Instrument: 5800; Special Factors: Phosphorylation emphasis, Species: Homo Sapiens; Quantitated tab: checked; ID Focus: Biological modification and Amino acid substitutions; Database: SwissProt_UniProt; Search Effort: Thorough ID; Minimum Detected Protein Threshold [Unused ProtScore (Conf)]: 1.3 (95.0\%); Run False Discovery Rate Analysis Tab: checked. The relative quantification was based on the ratio of the reporter ions corresponding to the $\mathrm{T}$ tryptic peptides $(117.1 \mathrm{Da})$ over the ratio of the NT (115.1 Da) reporter ions. Proteins giving tryptic peptides with an average reporter ion ratio $\geq 2$ were classified as up-regulated, otherwise those with an average reporter ion ratio $\leq 0.5$ were classified as downregulated [8]. All identified proteins were analyzed through the use of QUIAGEN 's Ingenuity ${ }^{\circledR}$ Pathway Analysis (IPA ${ }^{\circledR}$, QUIAGEN Redwood City, www .quiagen.com/ingenuity).

\section{ACKNOWLEDGMENTS}

This work was supported by a Post-Doctoral Research Fellowship from the MIUR (BANDO DI CONCORSO DR 2648/2014).

\section{CONFLICTS OF INTEREST}

The authors declare that they have no conflicts of interest.

\section{REFERENCES}

1. Jemal A, Siegel R., Xu J, Ward E. Cancer statistic 2010. CA Cancer J Clin. 2010; 60:277-300.
2. Lilja H, Ulmert D, Vickers AJ. Prostate-specific antigen and prostate cancer: Prediction, detection and monitoring. Nat Rev Cancer. 2008; 8:268-278.

3. Daskivich TJ, Chamie K, Kwan L, Labo J, Palvolgyi R, Dash A, Greenfield S, Litwin MS. Overtreatment of men with low-risk prostate cancer and significant comorbidity. Cancer. 2011; 117:2058-2066.

4. Rhodes DR, Barrette TR, Rubin MA, Ghosh D, Chinnaiyan AM. Meta-analysis of microarrays: Interstudy validation of gene expression profiles reveals pathway dysregulation in prostate cancer. Cancer Res. 2002; 62:4427-4433.

5. Napoli A, Aiello D, Di Donna L, Prendushi H, Sindona G. Exploitation of endogenous protease activity in raw mastitic milk by MALDI-TOF/TOF. Anal Chem. 2007; 79:5941-5948.

6. Ye B, Cramer DW, Skates SJ, Gygi SP, Pratomo V, Fu L, Horick NK, Licklider LJ, Schorge JO, Berkowitz RS, Mok SC. Haptoglobin-subunit as potential serum biomarker in ovarian cancer: Identification and characterization using proteomic profiling and mass spectrometry. Clin. Cancer Res. 2003; 9:2904-2911.

7. Ross P L, Huang Y N, Marchese J N, Williamson B, Parker K, Hattan S, Khainovski N, Pillai S, Dey S, Daniels S, Purkayastha S, Juhasz P, Martin S, Bartlet-Jones M, He F, Jacobson A, Pappin D J. Multiplexed Protein Quantitation in Saccharomyces cerevisiae Using Amine-reactive Isobaric Tagging Reagents. Molecular \& Cellular Proteomics. 2004; 3:1154-1169.

8. Garbis SD, Tyritzis SI, Roumeliotis T, Zerefos $P$, Giannopoulou EG, Vlahou A, Kossida S, Diaz J, Vourekas S, Tamvakopoulos C, Pavlakis K, Sanoudou D, Constantinides CA. Search for potential markers for prostate cancer diagnosis, prognosis and treatment in clinical tissue specimens using amine-specific isobaric tagging (iTRAQ) with two-dimensional liquid chromatography and tandem mass spectrometry. J Proteome Res. 2008; 7:3146-3158.

9. Sun C, Song C, Ma Z, Xu K, Zhang Y, Jin H, Tong S, Ding W, Xia G, Ding Q. Periostin identified as a potential biomarker of prostate cancer by iTRAQ-proteomics analysis of prostate biopsy. Proteome Sci. 2011; 19:9-22.

10. Mueller MM, Fusenig NE. Friends or foes-bipolar effects of the tumor stroma in cancer. Nature Reviews. 2004; 4:839-849.

11. Gleason DF, Mellinger GT: Prediction of prognosis for prostatic adenocarcinoma by combined histological grading and clinical staging. J. Urol. 1974; 111:58-64.

12. Humphrey PA, Gleason grading and prognostic factors in carcinoma of the prostate. Modern Pathology. 2004; 17:292-306.

13. Napoli A, Athanassopoulos CM, Moschidis P, Aiello D, Di Donna L, Mazzotti F, Sindona G. Solid Phase Isobaric Mass Tag Reagent for Simultaneous Protein Identification and Assay. Anal. Chem. 2010; 82:5552-5560. 
14. Napoli A, Aiello D, Aiello G, Cappello MS, Di Donna L, Mazzotti F, Materazzi S, Fiorillo M, Sindona G. Mass spectrometry-based proteomic approach in Oenococcus oeni enological starter. J Proteome Res. 2014; 13:2856-2866.

15. Aiello D, Materazzi S, Risoluti R, Thangavel H, Di Donna L, Mazzotti F, Casadonte F, Siciliano C, Sindona G, Napoli A. A major allergen in rainbow trout (Oncorhynchus mykiss): complete sequences of parvalbumin by MALDI tandem mass spectrometry. Mol BioSyst. 2015; 11:2373-2382.

16. Swindle MM, Makin A, Herron AJ, Clubb FJ Jr, Frazier KS. Swine as Models in Biomedical Research and Toxicology Testing. Vet Pathol. 2012; 49:344-356.

17. Napoli A, Aiello D, Di Donna L, Sajjad A, Perri E, Sindona G. Profiling of hydrophilic proteins from Olea europaea olive pollen by MALDI TOF mass spectrometry. Anal Chem. 2006; 78:3434-3443.

18. Jahouh F, Saksena R, Aiello D, Napoli A, Sindona G, Kovàc $\mathrm{P}$, Banoub JH. Glycation sites in neoglycoglycoconjugates from the terminal monosaccharide antigen of the O-PS of Vibrio cholerae O1, serotype Ogawa, and BSA revealed by matrix-assisted laser desorption-ionization tandem mass spectrometry. JMS. 2010; 45:1148-1159.

19. Zhan X, Desiderio DM. Signaling pathway networks mined from human pituitary adenoma proteomics data. BMC Med. Genomics. 2010; 3:13.

20. Terracciano R, Pasqua L, Casadonte F, Frascà S, Preianò M, Falcone D, Savino R. Derivatized mesoporous silica beads for MALDI-TOF MS profiling of human plasma and urine. Bioconjug Chem. 2009; 20:913-923.

21. Blume-Jensen $P$, Hunter T. Oncogenic kinase signalling. Nature. 2001; 411:355-365.

22. Agoulnik IU, Vaid A, Bingman WE, Erdeme H, Frolov A, Smith CL, Ayala G, Ittmann MM, Weigel NL. Role of SRC-1 in the promotion of prostate cancer cell growth and tumor progression. Cancer Res. 2005; 65:7959-7967.

23. Rajalingam K, Wunder C, Brinkmann V, Churin Y, Hekman M, Sievers C, Rapp UR, Rudel T. Prohibitin is required for Ras-induced Raf-MEK-ERK activation and epithelial cell migration. Nat. Cell Biol. 2005; 7:837-843.

24. Artal-Sanz M, Tavernarakis N. Prohibitin couples diapause signalling to mitochondrial metabolism during ageing in $\mathrm{C}$. elegans. Nature. 2009; 461:793-797.

25. Toska E, Shandilya J, Goodfellow SJ, Medler KF, Roberts SG. Prohibitin is required for transcriptional repression by the WT1-BASP1 complex. Oncogene. 2014; 33:5100-5108.

26. Sievers C, Billig G, Gottschalk K, Rudel T. Prohibitin are required for cancer cell proliferation and adhesion. PLoS One. 2010; 5:e12735.

27. Ummanni R, Junker H, Zimmermann U, Venz S, Teller S, Giebel J, Scharf C, Woenckhaus C, Dombrowski F, Walther R. Prohibitin identified by proteomic analysis of prostate biopsies distinguishes hyperplasia and cancer. Canc. Lett. 2008; 266:171-185.
28. Hall A. The cytoskeleton and cancer. Cancer Metastasis Rev $2009 ; 28: 5-14$.

29. Yamaguchi H, Condeelis J. Regulation of the actin cytoskeleton in cancer cell migration and invasion. Biochim Biophys Acta. 2007; 1773:642-652.

30. Taniwaki M, Takano A, Ishikawa N, Yasui W, Inai K, Nishimura H, Tsuchiya E, Kohno N, Nakamura Y, Daigo Y. Activation of KIF4A as a prognostic biomarker and therapeutic target for lung cancer. Clin Cancer Res. 2007; 13:6624-6631.

31. Corson TW, Gallie BL. KIF14 mRNA expression is a predictor of grade and outcome in breast cancer. Int J Cancer. 2006; 119:1088-1094.

32. Dorsam RT, Gutkind JS. G-protein-coupled receptors and cancer. Nat Rev Cancer. 2007; 7:79-94.

33. Marinissen MJ, Gutkind JS. G-protein-coupled receptors and signaling networks: emerging paradigms. Trends Pharmacol Sci. 2001; 22:368-376.

34. Blume-Jensen P, Hunter T. Oncogenic kinase signaling. Nature. 2001; 411:355-365.

35. Reddy E, Albanito L, De Marco P, Aiello D, Napoli A, Musti AM. Multisite phosphorylation of c-Jun at threonine 91/93/95 triggers the onset of c-Jun pro-apoptotic activity in cerebellar granule neurons. Cell Death Dis., 2013; 4:e852, doi: 10.1038/cddis.2013.381.

36. Sato I, Obata Y, Kasahara K, Nakayama Y, Fukumoto Y, Yamasaki T, Yokoyama KK, Saito T, Yamaguchi N. Differential trafficking of Src, Lyn, Yes and Fyn is specified by the state of palmitoylation in the SH4 domain. J Cell Sci. 2009, 122:965-975.

37. Weaver AM, Silva CM. Signal transducer and activator of transcription 5b: a new target of breast tumor kinase/protein tyrosine kinase 6. Breast Cancer Res. 2007; 9:R79.

38. Zheng Y, Peng M, Wang Z, Asara JM, Tyner AL. Protein tyrosine kinase 6 directly phosphorylates AKT and promotes AKT activation in response to epidermal growth factor. Mol Cell Biol. 2010; 30:4280-4292.

39. Zheng Y, Asara JM, Tyner AL. Protein-tyrosine Kinase 6 Promotes Peripheral Adhesion Complex Formation and Cell Migration by Phosphorylating p130 CRK-associated Substrate. J Biol Chem. 2012; 287:148-158.

40. Zheng Y, Tyner AL. Context-specific protein tyrosine kinase 6 (PTK6) signalling in prostate cancer. Eur J Clin Invest. 2013; 43:397-404.

41. Dhillon AS, Hagan S, Rath O, Kolch W. MAP kinase signalling pathways in cancer. Oncogene, 2007; 26:3279-3290.

42. Robertson BW, Bonsal L, Chellaiah MA. Regulation of Erk1/2 activation by osteopontin in PC3 human prostate cancer cells. Molecular Cancer. 2010; 9:260.

43. Erstad DJ, Cusack JC Jr. Targeting the NF- $\kappa$ B pathway in cancer therapy. Surg Oncol Clin N Am. 2013; 22:705-746.

44. Perkins ND. Post translational modification regulating the activity and function of the nuclear factor $\mathrm{kB}$ pathway. Oncogene. 2006; 25:6717-6730. 
45. Liu P, Cheng H, Roberts TM, Zhao JJ. Targeting the phosphoinositide 3-kinase pathway in cancer. Nat Rev Drug Discov. 2009; 8:627-644.

46. Engelman JA. Targeting PI3K signalling in cancer: opportunities, challenges and limitations. Nat Rev Cancer. 2009; 9:550-562.

47. Burris HA III. Overcoming acquired resistance to anticancer therapy: focus on the PI3K/AKT/mTOR pathway. Cancer Chemother Pharmacol. 2013; 71:829-842.

48. Pourmand G, Ziaee AA, Abedi AR, Mehrsai A, Alavi HA, Ahmadi A, Saadati HR. Role of PTEN gene in progression of prostate cancer. Urology Journal. 2007; 4:95-100.

49. Gao N, Zhang Z, Jiang BH, Shi X. Role of PI3K/AKT/ mTOR signaling in the cell cycle progression of human prostate cancer. Biochemical and Biophysical Research Communications. 2003; 310:1124-1132.

50. Whitaker HC, Girling J, Warren AY, Leung H, Mills IG, Neal DE. Alterations in beta catenin expression and localization in prostate cancer. Prostate. 2008; 68:1196-1205.

51. Segditsas S, Tomlinson I. Colorectal cancer and genetic alterations in the Wnt pathway. Oncogene. 2006; 25:7531-7537.

52. Ishigaki $K$, Namba $H$, Nakashima M, Nakayama $T$, Mitsutake N, Hayashi T, Maeda S, Ichinose M, Kanematsu $\mathrm{T}$, Yamashita S. Aberrant localization of beta catenin correlates with overexpression of its target gene in human papillary thyroid cancer. J Clin Endocrinol Metab. 2002; $87: 3433-3440$

53. Pawlak G, Helfman DM. Cytoskeletal changes in cell transformation and tumorigenesis. Curr Opin Genet Dev. 2001, 11:41-47.

54. Varisli L. Identification of new genes downregulated in prostate cancer and investigation of their effects on prognosis. Genet Test Mol Biomarkers. 2013; 17:562-566.

55. Franzen B, Linder S, Uryu K, Alaiya AA, Hirano T, Kato $\mathrm{H}$, Auer G. Expression of tropomyosin isoforms in benign and malignant human breast lesions. Br J Cancer. 1996; 73:909-913.

56. Aitken A. 14-3-3 proteins: a historic overview. Semin Cancer Biol. 2006; 16:162-172.

57. Van Hemert MJ, Steensma HY, van Heusden GP. 14-3-3 proteins: key regulators of cell division, signalling and apoptosis. Bioessays. 2001; 23:936-946.

58. Neal C L, Yao J, Yang W, Zhou X, Nguyen N T, Lu J, Danes C G, Guo H, Lan K H, Ensor J, Hittelman W, Hung M C, Yu D. 14-3-3zeta overexpression defines high risk for breast cancer recurrence and promotes cancer cell survival. Cancer Re. 2009; 69:3425-3432.

59. Murata T, Takayama K, Urano T, Fujimura T, Ashikari D, Obinata D, Horie-Inoue K, Takahashi S, Ouchi Y, Homma Y, Inoue S 14-3-3z a Novel Androgen-Responsive Gene
Is Upregulated in Prostate Cancer and Promotes Prostate Cancer Cell Proliferation and Survival. Clin Cancer Res. 2012; 18:5617-5627.

60. Jackson D E The unfolding tale of PECAM-1. FEBS Lett. 2003; 540:7-14.

61. Karagiannis G S, Saraon P, Jarvi K A, Diamandis E P. Proteomic Signatures of Angiogenesis in AndrogenIndependent Prostate Cancer. The Prostate. 2014; $74: 260-272$.

62. Priya D, Prasad \& Jo-Anne L, Stanton \& Stephen J. Assinder Expression of the actin-associated protein transgelin (SM22) is decreased in prostate cancer. Cell Tissue Res. 2010; 339:337-347.

63. Guertin D, Sabatini D M. Defining the Role of mTOR in Cancer. Cancer Cell. 2007; 12:9-22.

64. Davies H, Bignell G R, Cox C, Stephens P, Edkins S, Clegg S, Teague J., (...), Futreal, P A. Mutations of the BRAF gene in human cancer. Nature. 2002; 417:949-954.

65. van Gennip A H, van Kuilenburg A B. Defects of pyrimidine degradation: clinical molecular and diagnostic aspects. Adv. Exp. Med. Biol. 2000; 486:233-241.

66. Loffler M, Fairbanks LD, Zameitat E, Marinaki A M, Simmonds H A. Pyrimidine pathways in health and disease. TRENDS in Molecular Medicine. 2005; 11:430-437.

67. Wang J, Ding N, Li Y, Cheng H, Wang D, Yang Q, Deng Y, Yang Y, Li Y, Ruan X, Xie F, Zhao H, Fang X. Insulinlike growth factor binding protein 5 (IGFBP5) functions as a tumor suppressor in human melanoma cells. Oncotarget. 2015; 6:20636-20649.

68. Hemers E, Duval C, McCaig C, Handley M, Dockray GJ, Varro A. Insulin-Like Growth Factor Binding Protein-5 Is a Target of Matrix Metalloproteinase-7: Implications for Epithelial-Mesenchymal Signaling. Cancer Res. 2005; 65:7363-7369.

69. Bradford M M. Rapid and sensitive method for quantitation of microgram quantities of proteins utilizing the principle of protein-dye binding. Anal. Biochem. 1976; 72:248-254.

70. Mazzotti F, Di Donna L, Taverna D, Nardi M, Aiello D, Napoli A, Sindona G. Evaluation of dialdehydic antiinflammatory active principles in extra-virgin olive oil by reactive paper spray mass spectrometry. International Journal of Mass Spectrometry, 2013; 352:87-91.

71. Furia E, Aiello D, Di Donna L, Mazzotti F, Tagarelli A, Thangavel H, Napoli A, Sindona G. Mass Spectrometry and Potentiometry studies of $\mathrm{Pb}$ (II), $\mathrm{Cd}$ (II) and $\mathrm{Zn}$ (II) cystine complexes. Dalton Transaction. 2014; 43:1055-1062.

72. De Nino A, Di Donna L, Mazzotti F, Sajjad A, Sindona G, Perri E, Russo A, De Napoli L, Filice L. Oleuropein expression in olive oils produced from drupes stoned in a spring pitting apparatus (SPIA). Food Chemistry 2008; 106:677-684. 